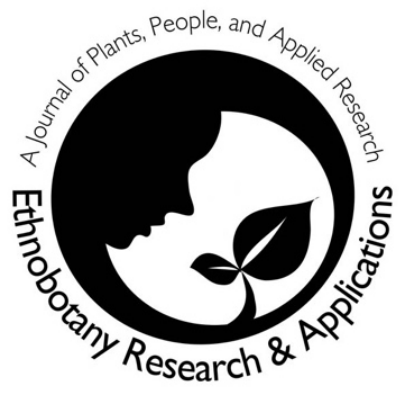

\title{
Ethnobotanical survey of medicinal plants in Taounate, Pre-Rif of Morocco
}

\author{
El-Mehdi El-Assri, Azeddin El Barnossi, Mohamed \\ Chebaibi, Anouar Hmamou, Hicham El Asmi, Abdelhak \\ Bouia and Noureddine Eloutassi
}

\begin{abstract}
Correspondence
El-Mehdi El-Assri ${ }^{1}$, Azeddin El Barnossi ${ }^{*}{ }^{*}$, Mohamed Chebaibi $^{2}$, Anouar Hmamou ${ }^{3}$, Hicham El Asmi ${ }^{4}$, Abdelhak Bouia $^{1}$ and Noureddine Eloutassi ${ }^{3}$

${ }^{1}$ Laboratory of Biotechnology, Environment, Agri-Food and Health, Faculty of Sciences Dhar El Mahraz, Sidi Mohammed Ben Abdellah University, Fez, Morocco

${ }^{2}$ Biomedical and translational research laboratory, Faculty of Medicine and Pharmacy, University of Sidi Mohamed Ben Abdellah, Fez, Morocco

${ }^{3}$ Laboratory of Engineering, Molecular Organometallic Materials and Environment Faculty of Sciences Dhar El Mahraz University Sidi Mohamed Ben Abdellah, Fez, Morocco

${ }^{4}$ Laboratory of Geodynamic, Environment and Associated Resources, Faculty of Sciences Dhar El Mahraz, Sidi

Mohammed Ben Abdellah University, Fez, Morocco.

${ }^{*}$ Corresponding Author: azeddin.elbarnossi@usmba.ac.ma
\end{abstract}

Ethnobotany Research \& Applications 22:36 (2021)

\section{Research}

\begin{abstract}
Background: Moroccan Pre-Rif is characterized by the abundance of its vegetable resources, especially its aromatic and medicinal plants. The Medicinal plants are used to treat certain diseases, as they have therapeutic properties. However, the region is not sufficiently studied, particularly in terms of its flora.
\end{abstract}

Objectives: The ethnobotanical study carried out in the province of Taounate (Pre-rif of Morocco) aims to collect information on the medicinal and aromatic plants used in phytotherapy in order to draw up a floristic inventory of the region, and to highlight this plant heritage.

Methods: An ethnobotanical survey was conducted among the population of some communes of the province of Taounate between May 2020 and May 2021. The study targeted people belonging to different categories of age, sex and family status. Data were collected using questionnaire forms based on structured interviews and analysed through the relative frequency of citation (RFC), the family importance value index (FIV) and the value of the plant part used (VPP).

Results: The analysis of the results obtained revealed a total of 111 medicinal plant species belonging to 52 botanical families, the most abundant of which are the Lamiaceae (FIV=13.327\%), the Asteraceae (FIV=6.164\%), the Apiaceae (2.878\%), the Fabaceae ( $F I V=5.07 \%)$ and the Rosaceae (FIV=2.998\%). The most cited species are Origanum compactum Benth (RFC= 43.81\%), Mentha pulegium L. (RFC=36.39\%), Rosmarinus officinalis L. (RFC=30.85\%), Chenopodium ambrosioides L. (RFC $=22.27 \%$ ). This analysis also allowed to determine that most of the diseases, especially digestive, are treated by the leaves of the plants which represent the most used plant part and also by decoction which constitutes the most frequent mode of preparation. 
Conclusion: According to the present survey, the population of the province of Taounate relies mainly on medicinal plants for treatment despite the development of modern medicine.

Keywords: Pre-rif of Morocco, Taounate, Medicinal plants, Ethnobotanical surveys, Traditional medicine.

\section{Background}

The use of medicinal plants to treat and cure diseases is an age-old practice that has developed in recent years (Benkhnigue et al. 2010; Jaadan et al. 2020). This development is generally due to both the increasing need for these plants, especially in developing countries, and their affordable cost compared to other synthetic medicines (El Hilah et al. 2016; Jaadan et al. 2020). In fact, these medicinal plants have therapeutic properties provided mainly by its active compounds that directly affect the body (Belyagoubi-Benhammou et al. 2017). The medicinal plants contain a wide variety of secondary metabolites such as tannins, alkaloids, phenolic compounds, and flavonoids (Djeussi et al. 2013). As the first source of new drugs, medicinal plants are used thanks to their antibacterial, antifungal, antioxidant, and antiviral activities, which are due to the phytochemicals synthesized in the secondary metabolism in the plants (Manandhar et al. 2019). Furthermore, A numbers of herbal textbooks mention various usages of medicinal plants to treat infectious diseases including urinary tract infections, gastrointestinal disorders, respiratory diseases, and cutaneous infections (Manandhar et al. 2019).

In African countries, namely Morocco, a major part of the population depends on these Medicinal plants as a source of healing (Tahri et al. 2012). Moreover, Morocco is one of the considerable floristic areas of North Africa due to its geographical position, topography, geology, climate, and its composite and differentiated environment (El Assri et al. 2021). Morocco contains a rich and diverse flora with approximately 743 taxa, 40 of them are endemic medicinal plants (Jamaleddine et al. 2017).

In view of this wealth, efforts are being made to preserve and enhance it. Thus, ethnobotanical surveys contribute to collecting the largest amount of information with a view to constituting a database for researchers in various fields, such as pharmacology, phytochemistry and toxicology (Jaadan et al. 2020). For the above reasons, the current study focused on the ethnobotanical survey of medicinal plants in the province of Taounate, and more particularly in six communes, four of which are rural; Bni Ounjel, Khlalfa, Jbabra, Ouartzagh and two are urban; Tissa and Taounate, for the main objective is the discovery of the richness of medicinal plants in the province of Taounate in view of a better valorization of these plants in the future.

\section{Materials and Methods}

\section{Study area}

The information concerning the study area was provided by the Regional Direction of Water and Forests and the Fight against Desertification of the north-eastern province of Taounate, Morocco. The province of Taounate is located in the Pre-Rif of Morocco (Figure 1). It covers an area of $5616 \mathrm{~km}^{2}$ within the Fez-Meknes region, divided between 44 rural and 5 urban communes. The population of this province amounts to 662,246 inhabitants (census, 2014) with a density of $117 \mathrm{inh} / \mathrm{km}^{2}$. About $87 \%$ of the population live in rural and spread over more than 1600 customs. The religion of the people is Islam, and Arabic is the official language of the country. In addition, the inhabitants of this region share a set of particular practices, and traditions, including speech, music, food, clothing, etc. The province is divided into two different parts: a northern part with mountainous terrain and a southern part with hilly terrain. The first part, which represents about $40 \%$ of the province's surface area, is linked to the Rifian domain, which is essentially made up of the forestry domain and covers an area of $40,690.96$ ha (7\% of the province's surface area). As for the southern part, which constitutes about $60 \%$ of the province's surface area, it is attached to the pre-Rifian zone. Taounate has a considerable hydrographic reserve, thanks to the Ouergha and of Inaouen rivers, and to the existence of reservoirs, such as Wahda, Idriss premier, Bouhouda, Sahla and Asfalou. This makes it possible to store a significant volume of water $\left(5.3\right.$ billion $\left.\mathrm{m}^{3}\right)$. The climate of this area is Mediterranean, characterised by the alternation of two seasons, one winter, wet and cold and the other summer, dry and hot. The average temperature is around $16.9{ }^{\circ} \mathrm{C}$ and can exceed $45^{\circ} \mathrm{C}$ in summer, and the average rainfall is around 790 $\mathrm{mm}$ and can reach $1800 \mathrm{~mm}$ at Jebel Outka. Taounate is also characterized by its wealth of plant resources, particularly aromatic and medicinal plants. 


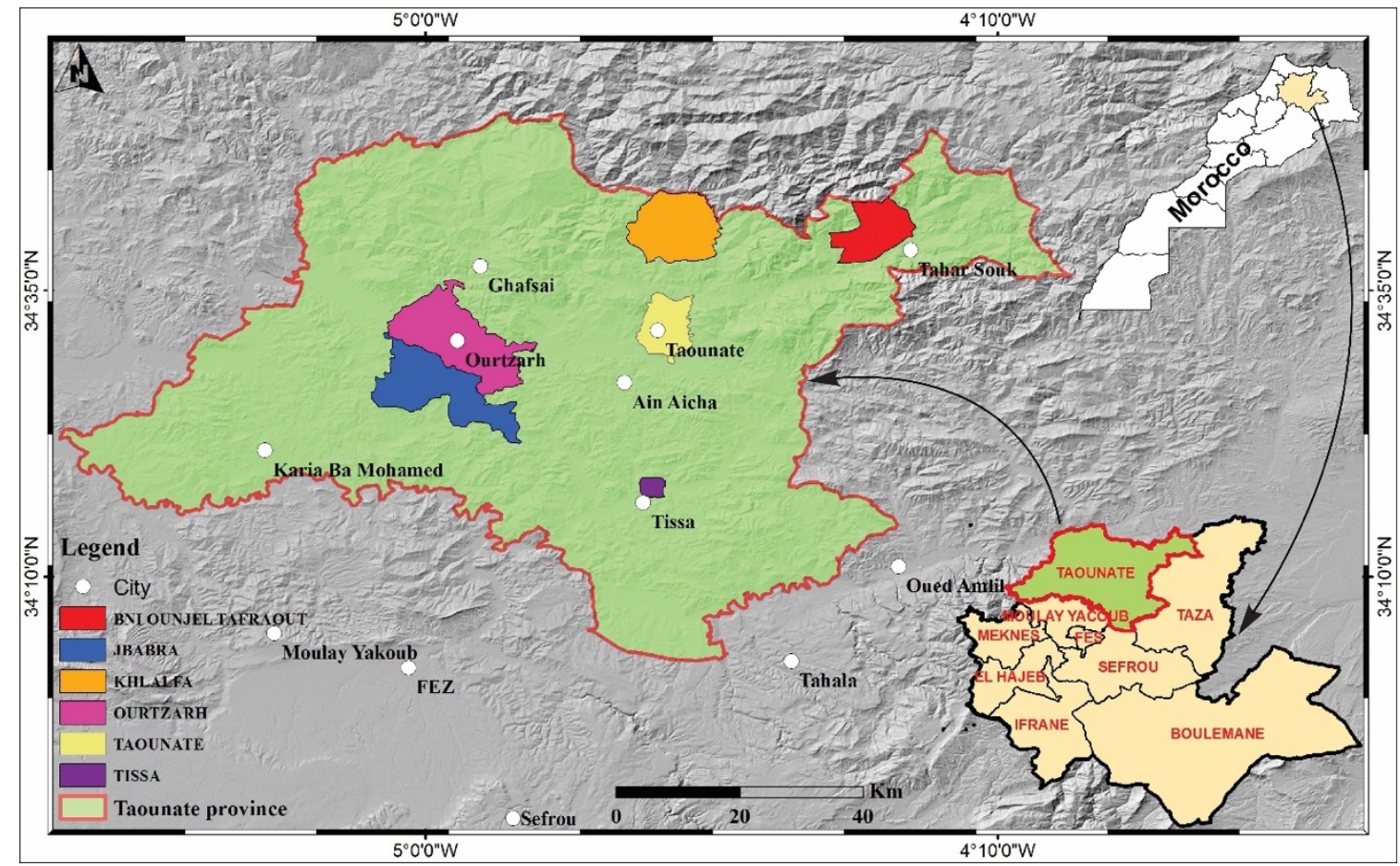

Figure 1. Map of the location of the study area. The map was prepared by QGIS software.

\section{Ethnobotanical survey}

An ethnobotanical survey was carried out in six communes of the province of Taounate (Bni Ounjel, Khlalfa, Jbabra, Ouartzagh, Tissa and Taounate) between May 2020 to May 2021. Closed-ended questionnaire was used to collect ethnobotanical data. The survey carried out from natives' residents. The questionnaire is divided into two parts; the first part concerns the profile of the informant, including age (under 20 years, 20 - 35 years, 35 - 55 years and over 55 years), gender (male and female), level of education, family situation, socio-economic level, place of residence, occupation, and the origin of the information. The second part concerns the plants used, the nature of use, the parts used, the diagnostic, the method of preparation, administration and conservation, the dosage, the type of plant, the collection period, the risk of toxicity, the results obtained and the side effects.

\section{Plant collection, handling, and identification}

The plant species collected in the field and then preserved in the herbarium. The collected plant species were identified at the Laboratory of Biotechnology, Environment, Agri-food and Health, Faculty of Sciences Dhar ElMahraz, Sidi Mohamed Ben Abdellah University, Fez, Morocco.

\section{Data analysis}

The data collected on the survey sheets were entered into a computer, processed, and analyzed statistically by GraphPad Prism 8.0.1 (Graph Pad Software Inc., San Diego, United States) and Microsoft Office "Excel 2016". The socio-demographic data of the participants were analyzed by a simple descriptive statistical analysis using percentages and frequencies. Ethnobotanical data were analyzed using relative frequency of citation (RFC), family importance value (FIV), and value of the plant part (VPP).

\section{Relative frequency of citation (RFC)}

RFC is an index that shows the importance of each species in the region studied. It is obtained by dividing the number of respondents having cited the species (FC), by the total number of respondents (N) (Tardío and Pardode Santayana, 2008):

$\mathrm{RFC}=\mathrm{FC} / \mathrm{N}(0<\mathrm{RFC}<1)$

\section{Family Importance Value (FIV)}

FIV represents the relative importance of families. It is used to assess the biological taxonomic value of plants, and is determined by dividing the number of respondents revealing the family (FC family) by the number of species within each family (Ns) (Sreekeesoon and Mahomoodally, 2014): 
$\mathrm{FIV}=\mathrm{FC}$ family $/ \mathrm{Ns}$

\section{Value of the plant part (VPP)}

VPP indicates the frequency of use of each of the plant parts. It is calculated by dividing the number of reported uses for all plant parts (RU plant part) by the sum of reported uses per plant part (RU) (Gomez-Beloz, 2002):

$\mathrm{VPP}=\mathrm{RU}$ plant part $/ R U$

\section{Results and Discussion}

Socio-demographic profile of informants

Six hundred eighty-seven (687) randomly selected natives and/or residents of the communes in six provinces of Taounate participated in the present study.

\section{Age and Gender}

In the survey area (Taounate region), most of the informants (46\%) were recorded in the 35-55 years age group followed by 20-34 years age group (29\%). The people who were under 20 and over 55 years old represent the lowest rate of users, with the percentage of $9 \%$ for the under 20 years old and a percentage of $16 \%$ for the over 55 years old (Table 1$)$. These results were done by ethnobotanical surveys conducted at the national level by Eddouks et al. (2002), Abouri et al. (2012) and Barkaoui et al. (2017), and at the international level by Skinner \& Rangasami (2002), Samake et al. (2012) and Silva et al. (2015). Therefore, the above 55 years group shows great interest in the use of herbal medicines, in contrast to the younger age group who seem to be unaware or even indifferent to this type of medication.

The use of medicinal plants in Taounate varies also according to gender. Females are in the lead with a percentage of $57 \%$ against $43 \%$ for males (Table 1). These data are similar to other studies by El Hilah et al. (2016), Jdaidi \& Hasnaoui (2016), Hamel et al. (2018) and Boutabia et al. (2020). This means that women attached great importance to traditional medicine contrary to men, because they believe that medicinal plants are effective in treating diseases from their cultural perception.

\section{Study level, family situation and socio-economic level}

The use of medicinal plants is very abundant among illiterate people. They had the highest rate of users (44\%), while university students have the lowest rate $(8 \%)$, because students do not believe that the using of medicinal plants can heal them. The remaining $48 \%$ of respondents are divided between primary (23\%) and secondary (25\%) level (Table 1). These results are similar to those reported by El hilah et al. (2016), Barkaoui et al. (2017) and Skalli et al. (2019).

In Taounate, married people used medicinal plants with a rate of $65 \%$, while single people had limited interest in these plants with a rate of $35 \%$ (Table 1). The results obtained by Lahsissene et al. (2010) and Mechchate et al. (2020) also showed that married people are the most knowledgeable about traditional herbal medicine.

The use of medicinal plants is more frequent among people with a low socioeconomic level than other with (53\%), because they believe that it is more effective. Moreover, the high socio-economic level used medicinal plants (10\%) (Table 1), due to the fact that they do not believe the effective of the medicinal plants. In contrast, it is less frequent among people with a medium socioeconomic level (37\%). These data are similar to the results of Alami Merrouni et al. (2021) and Jaddi et al. (2021).

\section{Profession and information origin}

Housewives are the category that uses medicinal plants most frequently, with a percentage of $37 \%$ of the people surveyed. Herbalists with a percentage of $8 \%$ have the lowest percentage. As for the other categories, $13 \%$ do not have a profession, $29 \%$ are farmers and the remaining $13 \%$ are civil servants (Table 1 ). Housewives used herbal medicines more than other categories of profession because they see that herbal medicine are effective, cheaper, and better than medication manufactured, and because they have great experiences, and because the impact on health is low compared to manufactured drugs. The current results are almost similar to the study of Jaadan et al. (2020) which focused on other regions of Morocco.

The majority of respondents (61\%) get information from the experience of others, $13 \%$ from their own reading and $21 \%$ from herbalists, while only $5 \%$ get their information from pharmacists, several factors could motivate this 
decision such as, beliefs, level of education, and living situation (Table 1). These results are in accordance with other studies done in the same region and in other regions of Morocco by Bellakhdar et al. (1991), Eddouks et al. (2002) and Es-Safi et al. (2020).

Table 1. Socio-demographic profile of the province of Taounate (Pre-rif of Morocco).

\begin{tabular}{llll}
\hline Variable & Sub-group & Number & Percentage (\%) \\
\hline \multirow{4}{*}{ Age } & $<20$ years & 60 & 9 \\
& $20-35$ years & 197 & 29 \\
& $35-55$ years & 320 & 47 \\
\hline \multirow{2}{*}{ Gender } & $>55$ years & 110 & 16 \\
\hline \multirow{4}{*}{ Study level } & Female & 389 & 57 \\
& Male & 298 & 43 \\
\hline \multirow{2}{*}{ Family status } & Analphabetic & 305 & 44 \\
& Primary & 155 & 23 \\
\hline \multirow{2}{*}{ Socio-economic level } & Secondary (College) & 93 & 14 \\
& Secondary (High School) & 79 & 11 \\
& University & 55 & 8 \\
\hline \multirow{3}{*}{ Information source } & Single & 242 & 35 \\
& Married & 445 & 65 \\
\hline \multirow{2}{*}{ Profession } & High & 70 & 10 \\
& Medium & 256 & 37 \\
& Low & 361 & 53 \\
\hline & Without & 89 & 13 \\
& Farmer & 201 & 29 \\
& Herbalist & 53 & 8 \\
& Civil servant & 91 & 13 \\
& Housewife & 253 & 37 \\
\hline & Bibliography & 87 & 13 \\
& Herbalist & 146 & 21 \\
& Pharmacist & 33 & 5 \\
& Experience of others & 421 & 61 \\
\hline
\end{tabular}

\section{Correlation between the information source and socio-demographic characteristics}

Table 2 shows a correlation between the information source and socio-demographic parameters. This result is in agreement with our study where there is a significant correlation $(R=0.879, P=0.0001)$ between the oldest informants and the experiences of others as a source of information. The current results are in accord with several ethnobotanical studies in Morocco which, shows the use of bibliography, such as books and/or visits to herbalists to provide information on plants (Haddad et al. 2003; Barkaoui et al. 2017).

Table 2. Correlation between information source and sociodemographic parameters.

\begin{tabular}{|c|c|c|c|c|c|c|c|}
\hline & & \multicolumn{4}{|c|}{ Information source } & \multirow[t]{2}{*}{ R Pearson } & \multirow[t]{2}{*}{ P value } \\
\hline & & Bibliography & Herbalist & Pharmacist & $\begin{array}{l}\text { Experience } \\
\text { of others }\end{array}$ & & \\
\hline \multirow{4}{*}{ Age } & $<20$ years $(\mathrm{N}=60)$ & 60 & 0 & 0 & 0 & \multirow{4}{*}{0.879} & \multirow{4}{*}{0.0001} \\
\hline & $20-35$ years $(\mathrm{N}=197)$ & 27 & 146 & 24 & 0 & & \\
\hline & $35-55$ years $(\mathrm{N}=320)$ & 0 & 0 & 9 & 311 & & \\
\hline & $>55$ years $(\mathrm{N}=110)$ & 0 & 0 & 0 & 110 & & \\
\hline \multirow{5}{*}{$\begin{array}{l}\text { Study } \\
\text { level }\end{array}$} & Analphabetic $(\mathrm{N}=305)$ & 87 & 146 & 33 & 39 & \multirow{5}{*}{0.657} & \multirow{5}{*}{0.0003} \\
\hline & Primary $(N=155)$ & 0 & 0 & 0 & 155 & & \\
\hline & Secondary (College) $(\mathrm{N}=93)$ & 0 & 0 & 0 & 93 & & \\
\hline & Secondary (High School) & \multirow[b]{2}{*}{0} & 0 & 0 & 79 & & \\
\hline & $\begin{array}{l}(\mathrm{N}=79) \\
\text { University }(\mathrm{N}=55)\end{array}$ & & 0 & 0 & 55 & & \\
\hline Socio- & High $(\mathrm{N}=70)$ & 70 & 0 & 0 & 0 & & \\
\hline economic & Medium $(N=256)$ & 17 & 146 & 33 & 60 & 0.871 & 0.0001 \\
\hline level & Low $(N=361$ & 0 & 0 & 0 & 361 & & \\
\hline
\end{tabular}




\section{Floristic analysis}

The different plant species inventoried are presented in Table 3 with their scientific name, vernacular name, genus, type, part used as well as data on the frequency of citation (RFC) and the family importance value (FIV). The present study collected 111 medicinal plant species belonging to fifty-two botanical families. Moreover, in Morocco, the number of medicinal plants is limited to 600 species (Rejdali, 1996; Bammi et al. 2002), that is $14.28 \%$ of all Moroccan plants (4200 species) (Fennane \& Ibn Tatou, 1991 and Bammi et al. 2002). Comparing the selected medicinal flora with the total flora, the study area has a rich biodiversity with a considerable number of medicinal plants.

In this study, Lamiaceae (16 species) represent the most used family with FIV $=13.327 \%$, followed by Asteraceae $(9$ species) with FIV $=6.149 \%$, Apiaceae ( 9 species) with $\mathrm{FIV}=2.878 \%$, Fabaceae ( 6 species) with $\mathrm{FIV}=5.07 \%$, and Rosaceae ( 5 species) with FIV $=2.998 \%$ (Figure 2). The representativeness of these families has also been observed in another ethnobotanical. Surveys conducted in the same region of Fez-Meknes (Es-Safi et al. 2020; El-Hilaly et al. 2003), and in other regions of Morocco (Barkaoui et al. 2017; Belhaj et al. 2020; El Hachlafi et al. 2020).

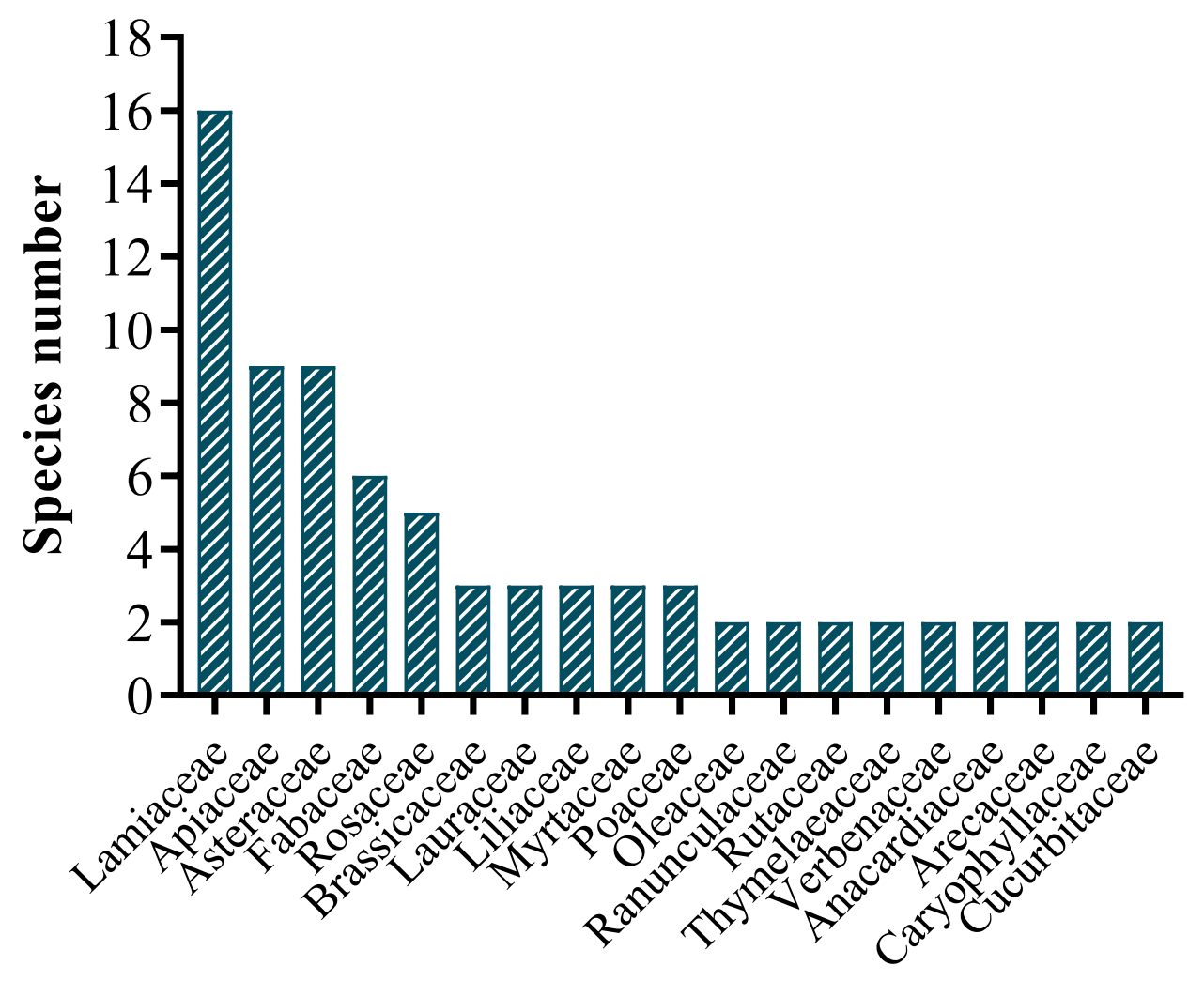

Familes

Figure 2. Botanical families most present in the province of Taounate.

The citation frequencies (CFR) of the plant species listed in the study area, vary from $0.29 \%$ to $43.81 \%$ with a predominance of the species Origanum compactum Benth (43.81\%), followed by Mentha pulegium L. (36.39\%), Rosmarinus officinalis L. (30.85\%), Chenopodium ambrosioides L. (22.27\%), Aloysia citriodora Palau (17.9\%), Allium sativum L. (17.61\%), Capparis spinosa L. (14.84\%), Artemisia herba-alba Asso (14.26\%), Mentha rotundifolia Muds (13.56\%) (Figure 3). These results are in accordance with those of Rhattas et al. (2016) and Mechchate et al. (2020). 


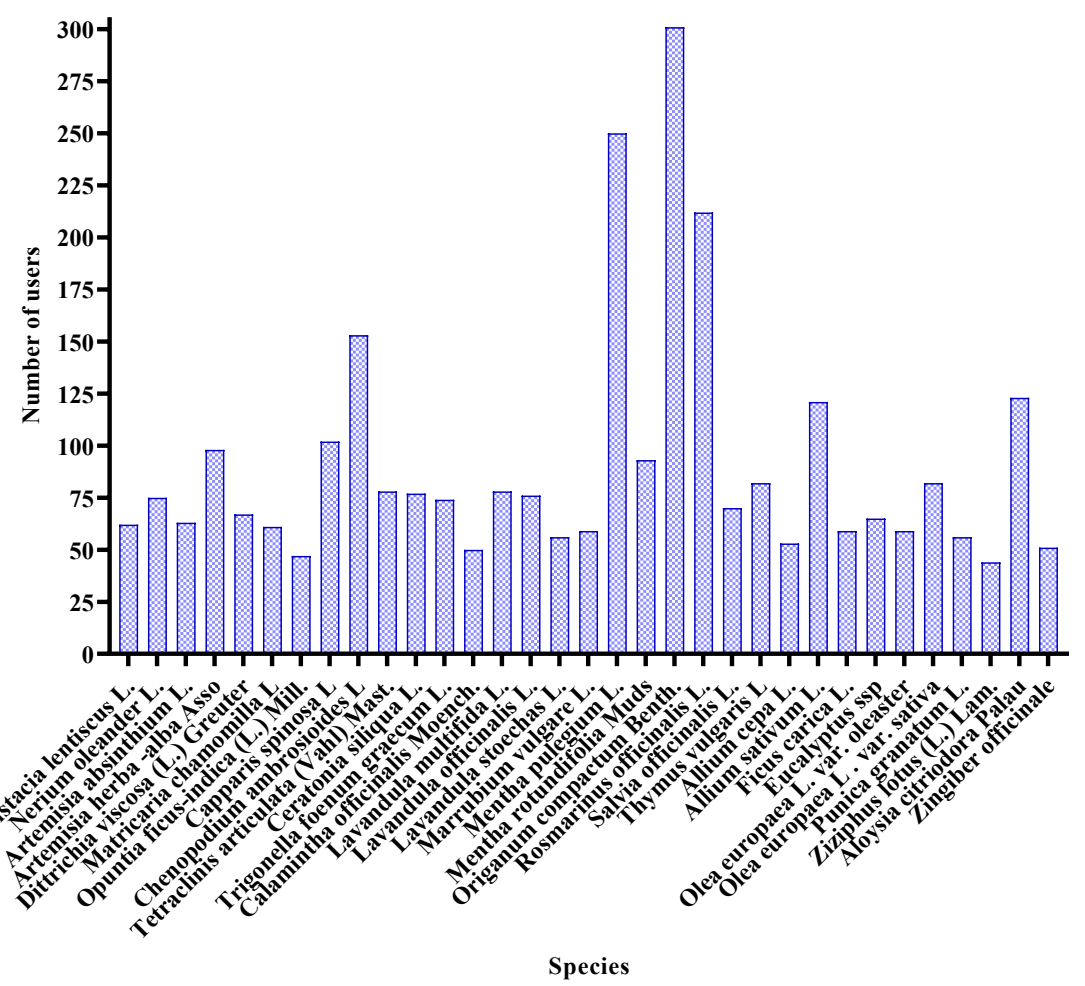

Figure 3. Frequency of use of plant species in northern Morocco (Taounate).

\section{Diagnosis}

In fact, most of the informants in the present study (74.80\%) diagnose their diseases themselves, as opposed to $2.77 \%$ who consult a doctor. while $22.43 \%$ go to an herbalist to recognize their ailments (Figure 4). These data are comparable with the study performed by Jaddi et al. (2021).

\section{Diagnosis}

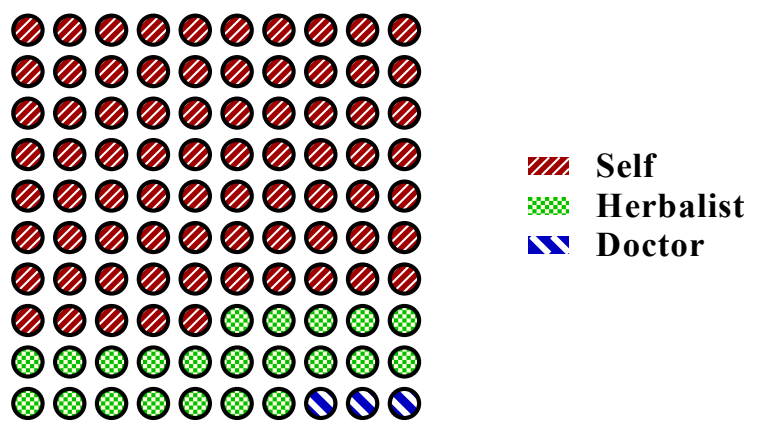

Figure 4. Distribution of medicinal plant users by type of diagnosis

\section{Plant parts used}

In the study area the leaves are the most used part with $P P V=0.277$. The aerial part comes second with VPP $=0.202$, followed by fruits (VPP=0.097), then stems (VPP=0.091), seeds (VPP=0.068), roots (VPP=0.066). For the other parts (whole plant, bulb, bark, rhizome), they are represented by a cumulative PPV $=0.115$ (Figure 5). Although these results show some similarities with those of (Salhi et al. 2010; Labiad et al. 2020), they are in contrast with those of (Mechchate et al. 2020) who show that seeds are the most frequently used parts with a percentage of $33 \%$. Indeed, the use of leaves is explained by the fact that they are easy to harvest, and that they constitute the centre of photosynthesis and storage of secondary metabolites responsible for biological properties (Tahri et al. 2012; Slimani et al. 2016). 


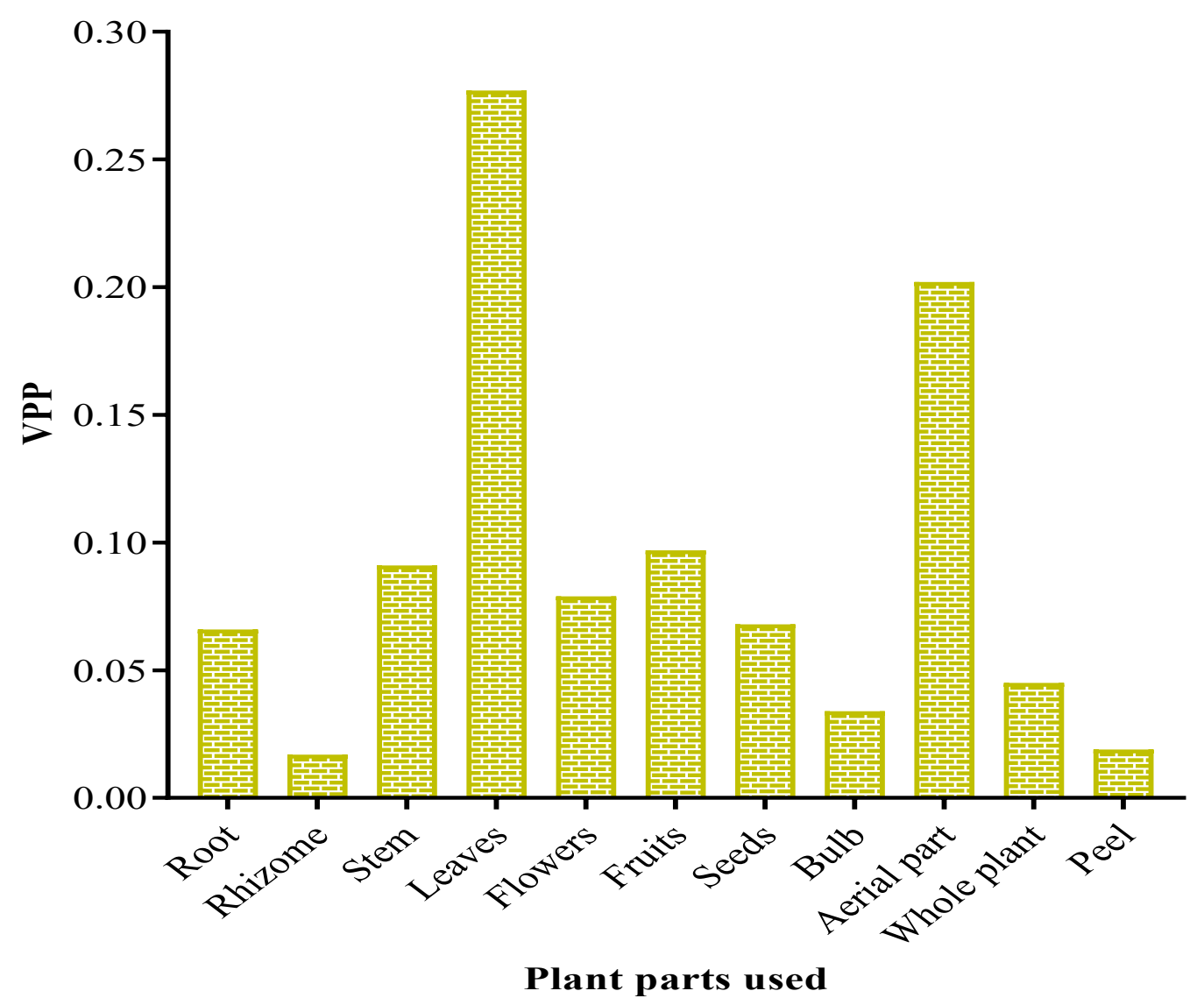

Figure 5. Different parts used of medicinal plants in the survey area.

\section{Method of preparation and mode of administration}

The local population of Taounate practices different techniques of preparation of medicinal plants, especially, decoction, infusion, maceration, fumigation. The decoction is the method of preparation used to extract the active principles of plants, with a percentage of $25.18 \%$. Infusion comes second with a percentage of $22.50 \%$, followed by cataplasm with $11.94 \%$. As for the other methods of preparation, fumigation is used with $9.99 \%$, maceration with $9.36 \%$, consumption of the powdered and crushed plant with $8.61 \%$ and $5.13 \%$ respectively. The remaining methods (use of raw plant, cooked plant, etc) represent a cumulative percentage of $7.29 \%$ (Figure 6). These results are broadly similar to those of other studies conducted in other regions of Morocco by Belhaj et al. (2020), El Hachlafi et al. (2020) and Alami et al. (2021).

The methods of administration of medicinal plants depend on the nature of the active ingredients and the degree of their toxicity. They can be administered internally (Orally, inhalation), or externally (Massage, rinsing). In this survey, most plants (57.61\%) are taken orally, $16.17 \%$ by rinsing and $11.56 \%$ by inhalation. The other modes of use, namely massage, represent a rate of 7.38\% (Figure 7A). Moreover, other studies by El Alami et al. (2017) and El Hachlafi et al. (2020) reported the same results, especially regarding the preponderance of the oral mode of administration. Furthermore, as shown (Figure 7B), water is the most commonly used solvent for herbal preparations with a rate of $45.66 \%$, followed by olive oil with a rate of $21.28 \%$. For the other solvents (Milk and honey), they share a rate of $20.39 \%$. The remaining $12.67 \%$ of the population do not use any solvent. Moreover, the study by Labiad et al. (2020) shares the same results. 


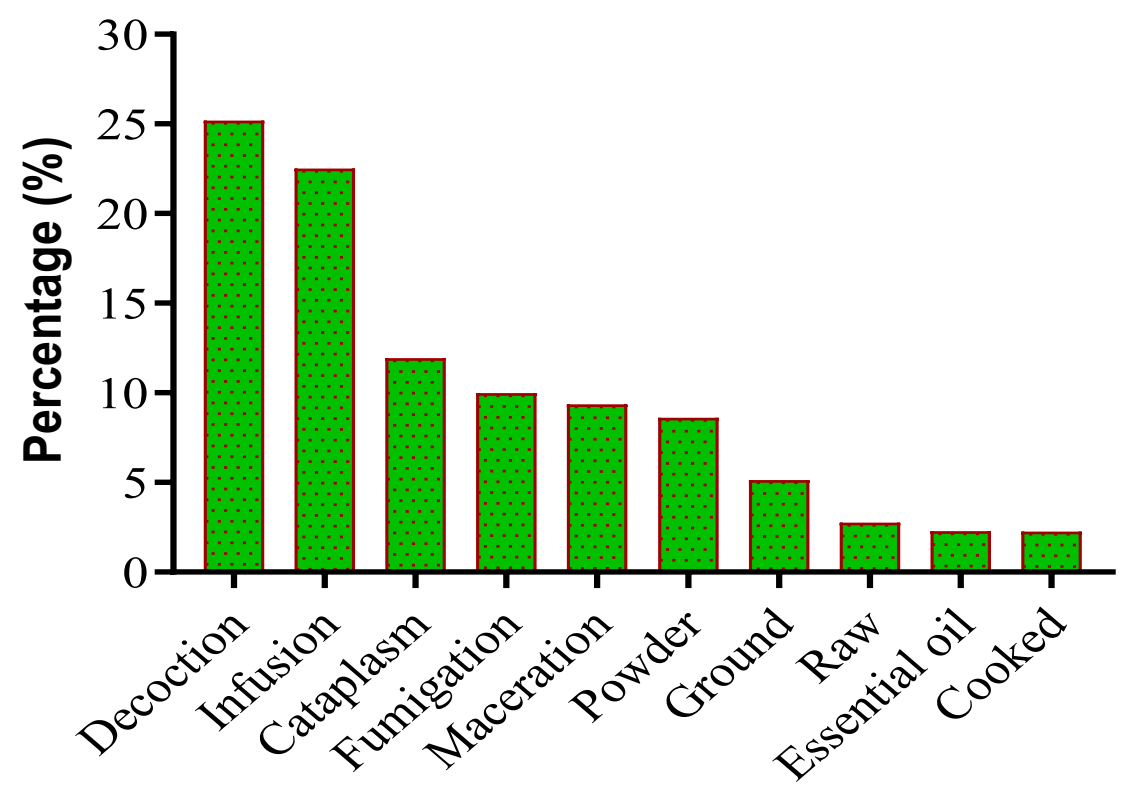

\section{Preparation methods}

Figure 6. Different preparation methods of the plants used in the study area

(A)

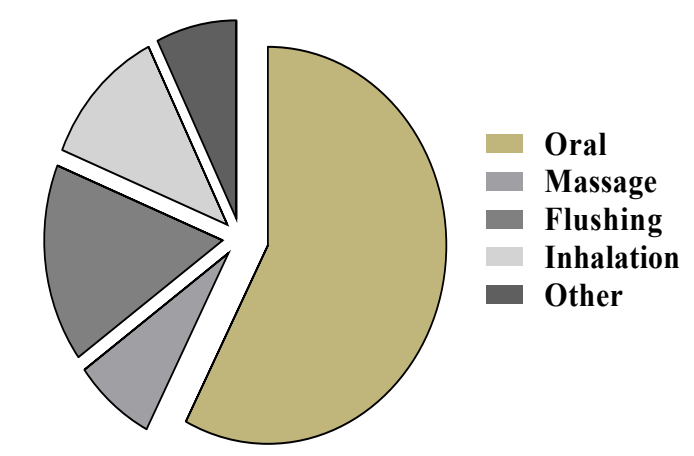

(B)

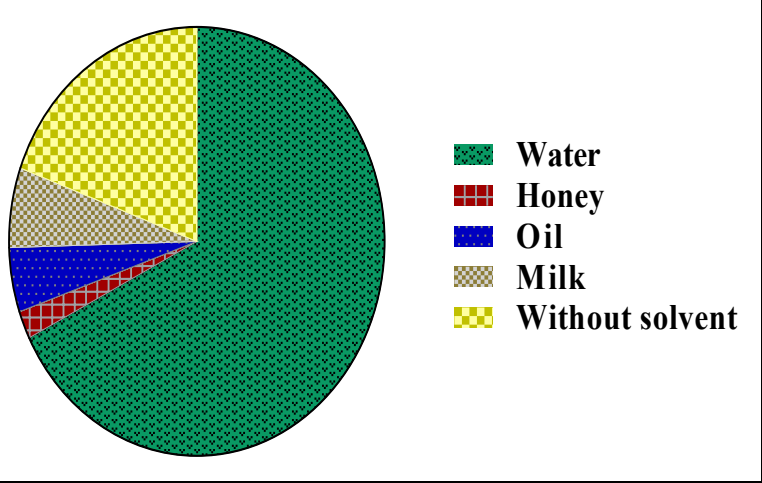

Figure 7. Mode of administration and solvents used. A. Different ways of medicinal plant administration, B. Proportions of solvents used in the preparation of medicinal plants.

\section{Posology}

In this survey area, a high number of respondents use medicinal plants without any specific dose. In fact, according to the results obtained, the spoonful is the most used dose with a percentage of $32.67 \%$, followed by the glass with a percentage of $32.02 \%$ (Figure 8 ). In addition to these doses, the pinch with a percentage of $18.39 \%$ and the handful with a percentage of $16.92 \%$ (Figure 8 ). Concerning the duration of using medicinal plants by the local population was $48.84 \%$ use for one week. As well as $35.67 \%$ for one day, and $5.79 \%$ for one month, for others the duration was not specific. The use of medicinal plants in unspecified dosages can lead to adverse effects as some plant species become toxic if misused (Benkhnigue et al. 2010; El Hachlafi et al. 2020).

\section{Diseases treated}

The analysis of the data collected reveals that the majority of the local population (68.98\%) uses medicinal plants for therapeutic purposes and $8.20 \%$ of this population uses them for food purposes (Figure 9). The most common diseases treated with medicinal plants are digestive diseases with a rate of $25 \%$. Respiratory diseases come next with a rate of $19.10 \%$, followed by dermatological diseases (10.79\%), metabolic disorders (7.29\%) and osteoarticular diseases (7.29\%). Other diseases, such as neurological diseases, hair diseases, ENT diseases, cardiovascular diseases, genitourinary diseases and dental diseases are moderately cited, with rates varying between $4.56 \%$ and $2.45 \%$. 
Diabetes (2.02\%), eye diseases (1.84\%) and cancer (0.45\%) are the least treated diseases with very low rates (Figure 10). These findings are almost in line with those already obtained in the Pre-rif of Morocco by El-Hilaly et al. (2003), in the North-East of Morocco by Alami et al. (2021), in the province of Laâyoune by Yahyaoui et al. (2015), and in the region of Gharb by Bouayyadi et al. (2015).

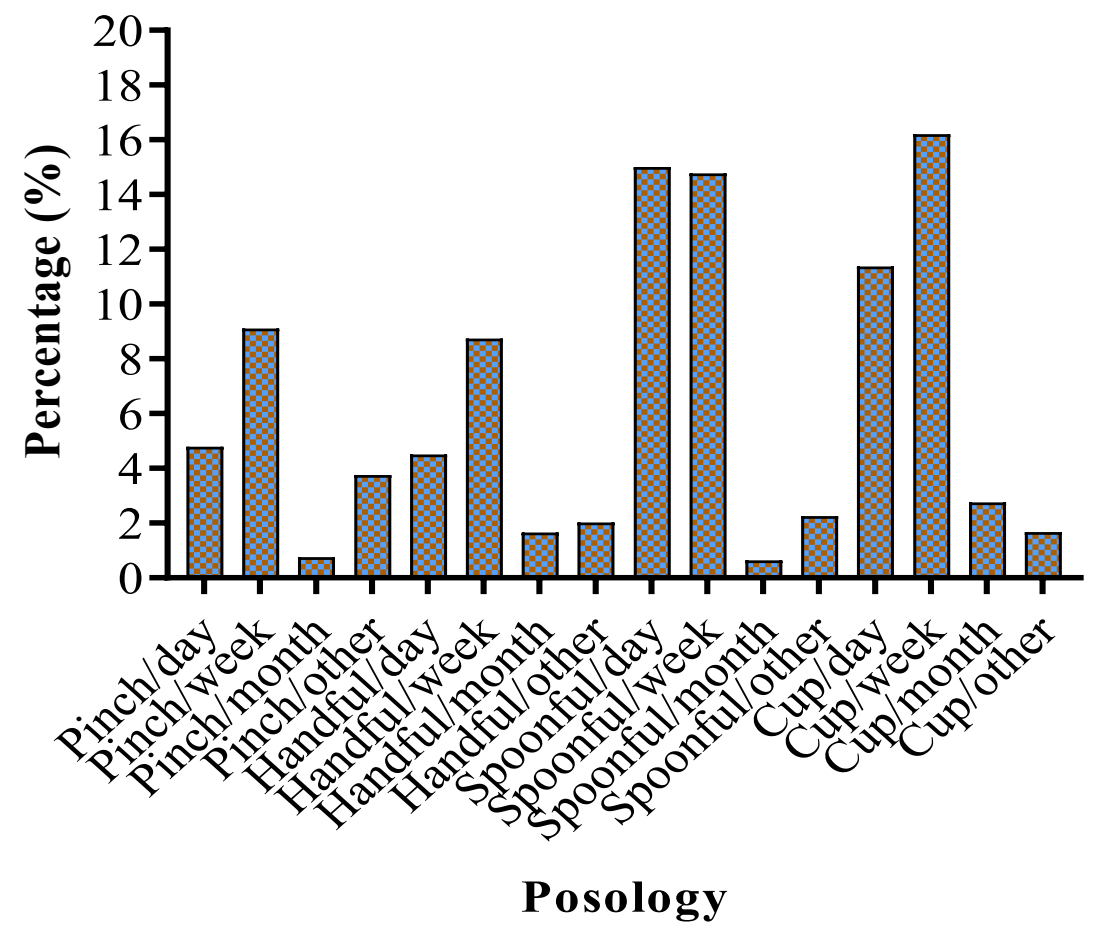

Figure 8. Distribution of herbal medicine users by dose and duration of treatment.

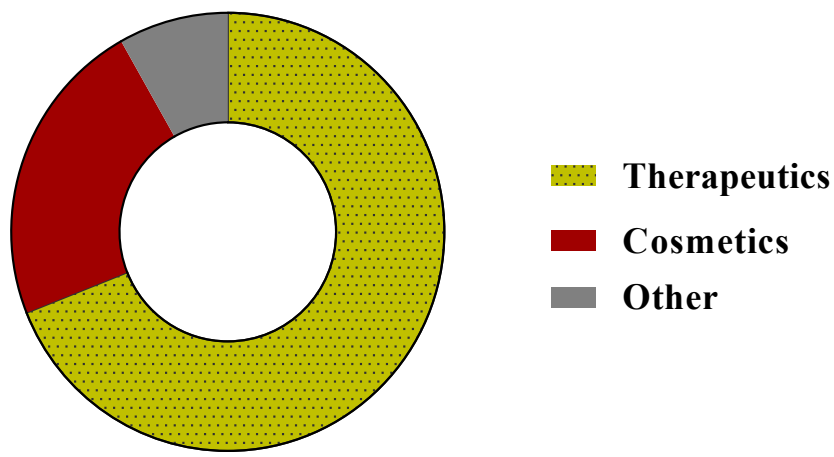

Figure 9. Medicinal and aromatic plant utilisation in the study area.

\section{Women's knowledge about the use of medicinal and aromatic plants}

Among the surveyed women, $50.64 \%$ believe that medicinal plants have a relieving effect, while $41.12 \%$ believe in the healing power of these plants. The rest (8.25\%) assumed that these plants do not have any desirable effect (Figure 11). These results are identical to those obtained by Benkhnigue et al. (2010) who show that $52 \%$ of the respondents recorded a simple improvement, while $40 \%$ declared to be cured, against $8 \%$ who noticed some side effects. 

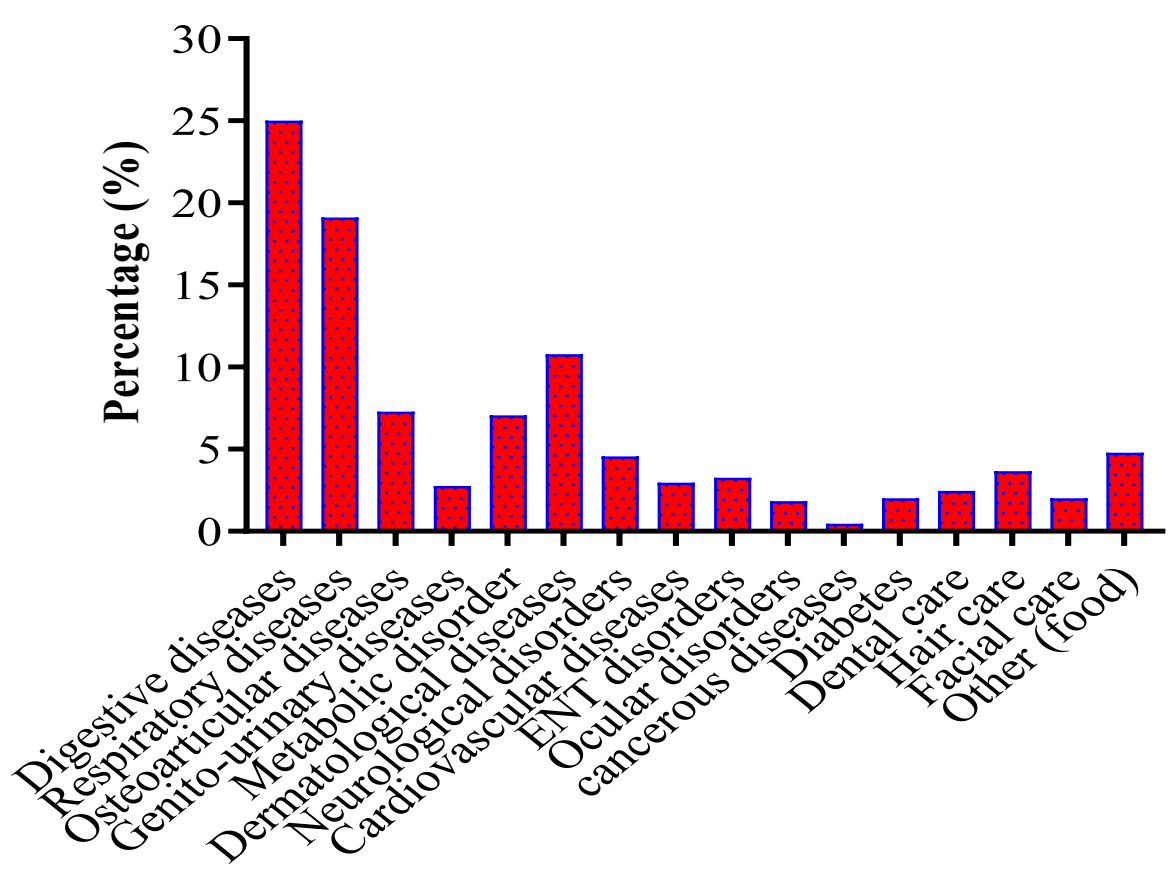

Treated diseases

Figure 10. Treated diseases by medicinal plants in the province of Taounate.

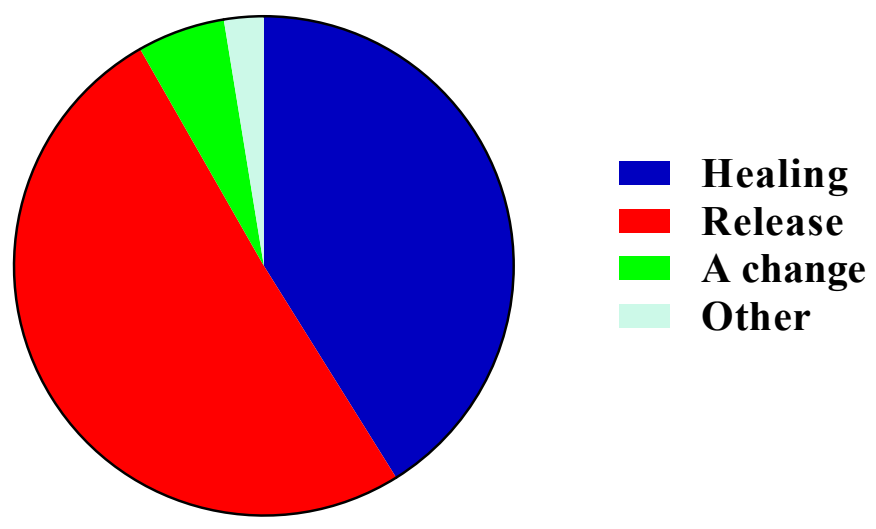

Figure 11. Women's knowledge about the use of medicinal and aromatic plants.

\section{Conclusion}

The ethnobotanical survey carried out in the province of Taounate revealed a good deal of information related to the use of medicinal plants in traditional phytotherapy. The results reveal that the local population mainly treats themselves with medicinal plants. it should be noted that there is a close link between the frequency of use of plants and the profile of the people interviewed. Thus, people between the 35-55 years years and women make the most use of medicinal plants. In addition, people with no schooling and from a low socio-economic level also choose traditional medicine. It should also be noted that the floristic analysis carried out identified 52 families with a clear predominance of Lamiaceae, Asteraceae, Apiaceae, Fabaceae and Rosaceae. and 111 species with a strong preponderance of Origanum compactum Benth, Mentha pulegium L., Rosmarinus officinalis L., Chenopodium ambrosioides L., Aloysia citriodora Palau, Allium sativum L., Capparis spinosa L., Artemisia herba alba Asso, Mentha rotundifolia Muds. This analysis also showed that the leaves are the most used parts, decoction is the most frequent mode of preparation, and the oral route is the most common mode of administration. In terms of the pathologies treated, the majority of medicinal plants are used to treat digestive diseases. 
In view of the conclusions obtained in the current survey, it appears that the use of medicinal and aromatic plants in the treatment of diseases by the local population is very important, despite the improved accessibility to care and modern medicine. Ultimately, the present study could be used as a source of information that will help in the knowledge of the medicinal flora of the province of Taounate and in the conservation of the knowledge and the practice of the local population.

\section{Declarations}

List of abbreviations: RFC: The relative frequency of citation, FIV: The family importance value index, VPP: The value of the plant part used, FC: The number of respondents having cited the species, $\mathrm{N}$ : The total number of respondents, FC family: The number of respondents revealing the family, Ns: The number of species within each family, RU plant part: The number of reported uses for all plant parts, RU: The sum of reported uses per plant part, CFR: The citation frequencies.

Ethics approval and consent to participate: Informed prior consent was obtained from all respondents before commencement of the interview. All data were collected with respect to confidentiality, anonymity and consent.

Consent for publication: Not applicable.

Availability of data and materials: The data was not deposited in public repositories.

Competing interests: The authors declare that they have no known competing financial interests or personal relationships that could have appeared to influence the work reported in this paper.

Funding: This study did not receive any specific grant from funding agencies in the public, commercial, or not-forprofit sectors.

Authors' contributions: El-mehdi El-Asri and Azeddin El Barnossi: Study design, Ethnobotanical survey conduction, active participation in structuring of the methodology, data analysis and interpretation, writing, original draft and review-editing. Mohamed Chebaibi, Anouar Hmamou and Hicham El Asmi: Methodology description and botanical identification, contribution to the study design and data analysis. Abdelhak Bouia and Noureddine Eloutassi: Work supervising, manuscript improving and review-editing. All authors read, reviewed, and approved the manuscript.

\section{Acknowledgements}

The authors are grateful for the scientific support provided by the Laboratory of Biotechnology, Environment, AgriFood and Health, Faculty of Sciences Dhar El Mahraz, Sidi Mohammed Ben Abdellah University, Fez, Morocco. We would also like to acknowledge all those who contributed, directly or indirectly, to this study, in particular Pr. Brahim El Bahraoui, the people interviewed, the kind reviewers and the editor.

\section{Literature cited}

Abouri M, El Mousadik A, Msanda, F, Boubaker H, Saadi B, Cherifi K. 2012. An ethnobotanical survey of medicinal plants used in the Tata Province, Morocco. International Journal of Medicinal Plant Research 1(7):99-123.

Alami M, Kharchoufa L, Bencheikh N, Elachouri M .2021. Ethnobotanical profile of medicinal plants used by people of North-eastern Morocco: Cross-cultural and Historical approach (Part I). Ethnobotany Research \& Applications 21:1-45. doi.org/10.32859/era.21.34.1-45.

Bammi J, Douira A. 2002. Les plantes médicinales dans la forêt de l'achach (plateau central, Maroc). Acta Botanica Malacitana 27:131-145.

Barkaoui M, Katiri A, Boubaker H, Msanda F. 2017. Ethnobotanical survey of medicinal plants used in the traditional treatment of diabetes in Chtouka Ait Baha and Tiznit (Western Anti-Atlas), Morocco. Journal of Ethnopharmacology 198:338-350. doi:10.1016/j.jep.2017.01.023.

Belhaj S, Dahmani J, Belahbib N, Zidane L. 2020. Ethnopharmacological and Ethnobotanical study of Medicinal plants in the Central High Atlas, Morocco الدراسة الايثنوفركولوجية والإثنوبولوجية للنباتات الطبية في الاطلس المتوسط الكبير للمغرب. Ethnobotany Research and Applications 20:1-40.

Belyagoubi-Benhammou N, Belyagoubi L, Bechlaghem N, Ghembaza N, Atik-Bekkara F.2017. Assessment of antioxidant potential and phytochemical analysis of Pituranthosscoparius crude extract and its fractions. Journal of Oriental Pharmacy and Experimental Medicine 17:51-57.

Bellakhdar J. 1997. La pharmacopée marocaine traditionnelle. Médecine arabe ancienne et savoirs populaires. Editions Le Fennec, Casablanca/ Ibis Press. 764 p. Paris. 
Benkhnigue O, Zidane L, Fadli M, Elyacoubi H, Rochdi A, Douira A. 2010. Etude ethnobotanique des plantes médicinales dans la région de Mechraâ Bel Ksiri (Région du Gharb du Maroc). Acta Botanica Barcinonensia 53:191216.

Benlamdini N, Elhafian M, Rochdi A, Zidane L. 2014. Etude floristique et ethnobotanique de la flore médicinale du Haut Atlas oriental (Haute Moulouya). Journal of Applied Biosciences 78(1):6771-6787. doi:10.4314/jab.v78i1.17

Bouayyadi L, El Hafian M, Zidane L. 2015. Etude floristique et ethnobotanique de la flore médicinale dans la région du Gharb, Maroc. Journal of Applied Biosciences 93:8770-8788. doi:10.4314/jab.v93i1.10.

Boutabia L, Telailia S, Menaa M. 2020. Utilisations thérapeutiques traditionnelles du Marrubium vulgare L. par les populations locales de la région de Haddada (Souk Ahras, Algérie) - Traditional therapeutic uses of Marrubium vulgare L. by local populations in the Haddada region (Souk Ahras, Algeria). Ethnobotany Research and Applications 19: 1-11.

Bouyahya A, Abrini J, Et-Touys A, Bakri Y, Dakka N. 2017. Indigenous knowledge of the use of medicinal plants in the North-West of Morocco and their biological activities. European Journal Integrative Medicine 13:9-25. doi:10.1016/j.eujim.2017.06.004.

Chebat A, Skalli S, Errihani H, Boulaâmane L, Mokrim M, Mahfoud T, Soulaymani R, Kahouadji A. 2014. Étude de prévalence des effets indésirables liés à l'utilisation des plantes médicinales par les patients de l'Institut National d'Oncologie, Rabat. Phytothérapie 12(1):25-32. doi:10.1007/s10298- 013-0828-4.

Djeussi DE, Noumedem JA, Seukep JA, Fankam AG, Voukeng IK, Tankeo SB, Kuete V. 2013. Antibacterial activities of selected edible plants extracts against multidrug-resistant Gram-negative bacteria. BMC Complementary and Alternative Medicine 13: 164. https://doi.org/10.1186/1472-6882-13-164

Doukkali Z, Bouidida H, Srifi A, Taghzouti K, Cherrah Y, Alaoui K. 2015. Les plantes anxiolytiques au Maroc. Études ethnobotanique et ethnopharmacologique. Phytothérapie 13(5):306-313. doi:10.1007/s10298-015-0921-z

Eddouks M, Ajebli M, Hebi M. 2017. Ethnopharmacological survey of medicinal plants used in Daraa-Tafilalet region (Province of Errachidia) Morocco. Journal of Ethnopharmacology 198:516-530. doi:10.1016/j.jep.2016.12.017.

Eddouks M, Maghrani M, Lemhadri A, Ouahidi ML, Jouad H. 2002. Ethnopharmacological survey of medicinal plants used for the treatment of diabetes mellitus, hypertension and cardiac diseases in the south-east region of Morocco (Tafilalet). Journal of Ethnopharmacology 82:97-103. doi:10.1016/S0378- 8741(02)00164-2

El Alami A, Chait A. 2017. Enquête ethnopharmacologique et ethnobotanique sur les plantes médicinales dans le Haut Atlas central du Maroc. Algerian Journal of Natural Products 1:427- 445.

El Amrani F, Rhallab A, Alaoui T, El Badaoui K, Chakir S. 2010. Étude ethnopharmacologique de quelques plantes utilisées dans le traitement du diabète dans la région de Meknès-Tafilalet (Maroc) Phytothérapie 8(3):161-165

El Hachlafi N, Chebat A, Bencheikh RS, FikriBenbrahim K. 2020. Ethnopharmacological Study of Medicinal Plants Used for Chronic Diseases Treatment in Rabat-Sale-Kenitra Region (Morocco). Ethnobotany Research and Applications 20:1-23.

El Hafian M, Benlandini N, Elyacoubi H, Zidane L, Rochdi A. 2014. Étude floristique et ethnobotanique des plantes médicinales utilisées au niveau de la préfecture d'Agadir-lda-Outanane (Maroc). Journal of Applied Biosciences 81(1):7198-7213

El Hassani M, Douiri EM, Bammi J, Zidane L, Badoc A, Douira A. 2013. Plantes Médicinales de La Moyenne Moulouya (Nord-Est Du Maroc). Ethnopharmacologia 50:39-53.

El Hilah F, Ben Akka F, Bengueddour R, Rochdi A, Zidane L. 2016. Etude ethnobotanique des Plantes Médicinales utilisées dans le traitement des affections dermatologiques dans le plateau central Marocain. Journal of Applied Biosciences 98:9252- 9260.

El Yahyaoui O, Ouaaziz NA, Sammama A, Kerrouri S, Bouabid B, Lrhorfi LA, Bengueddour, R. 2015. Ethnobotanical Study: Medicinal plants commercialized in the province of Laayoune; identification and use. International Journal of Innovation and Applied Studies 12(3):533. 
El-Assri E, Eloutassi N, El Barnossi A, Bakkari F, Hmamou A, Bouia B. 2021. Wild Chamomile (Matricaria recutita L) from the Taounate Province, Morocco: Extraction and Valorisation of the Antibacterial Activity of its Essential Oils. Tropical Journal of Natural Product Research. Trop J Nat Prod Res 5(5):883-888.

El-Hilaly J, Hmammouchi M, Lyoussi B. 2003. Ethnobotanical Studies and Economic Evaluation of Medicinal Plants in Taounate Province (Northern Morocco). Journal of Ethnopharmacology 86(2- 3):149-58.

Es-Safi I, Mechchate H, Amaghnouje A, Jawhari F, Bari A, Cerruti P, Avella M, Grafov A, Bousta D.2020. Medicinal plants used to treat acute digestive system problems in the region of Fez-Meknes in Morocco: An ethnopharmacological survey. Ethnobotany Research \& Applications 20:1-14. doi.org/10.32859/era.20.25.1-14.

Fadil M, Farah A, Haloui T, Rachiq S. 2015. Étude ethnobotanique des plantes exploitées par les coopératives et les associations de la région Meknès-Tafilalet au Maroc. Phytothérapie 13(1):19- 30. doi:10.1007/s10298-014-0902-2.

Fennane M, Ibn Tattou M .1991. Aperçu historique et état actuel des connaissances sur la flore vasculaire du Maroc. Bulletin de l'institut Scientifique, Rabat 13:85-94.

Ghourri M, Zidane L, Douira A. 2013. Catalogue of medicinal plants used in the treatment of renal lithiasis in the province of Tan-Tan (Saharan Morocco). International Journal of Biological and Chemical Sciences 7(4):1688-1700. doi:10.15171/jrip.2016.27.

Gomez-Beloz A. 2002. Plant use knowledge of the Winikina Warao: the case for questionnaires in ethnobotany. Economic Botany 56(3):231-241.

Hachi M, Hachi T, Belahbib N, Dahmani J, Zidane L. 2015. Contribution à L'Etude Floristique Et Ethnobotanique De La Flore Medicinale Utilisée Au Niveau De La Ville De Khenifra (Maroc) [Contribution To the Study and Floristic Ethnobotany Flora Medicinal Use At the City of Khenifra (Morocco)]. International Journal of Innovation and Applied Studies 11(3):754-770.

Haddad PS, Depot M, Settaf A, et al (2003) Comparative study on the medicinal plants most recommended by traditional practitioners in Morocco and Canada. J Herbs Spices Med Plants 10:25-45

Hamel T, Sadou N, Seridi R, Boukhdir S, Boulemtafes A. 2018. Pratique traditionnelle d'utilisation des plantes médicinales dans la population de la péninsule de l'Edough (nord-est algérien). Ethnopharmacologia 59:65-71.

Hseini S, Kahouadji A. 2007. Étude ethnobotanique de la flore médicinale dans la région de Rabat (Maroc occidental). Lazaroa 28:79-93. doi: 10.1007/s10298-015-0953-z.

Jaadan H, Akodad M, Moumen A, Baghour M, Skalli A, Ezrari S, Belmalha S.2020. Ethnobotanical survey of medicinal plants growing in the region of "Oulad Daoud Zkhanine" (Nador Province), in Northeastern Morocco. Ethnobotany Research \& Applications 19:1-12. doi.org/10.32859/era.19.39.1-12.

Jamaleddine M, El Oualidi J, Taleb MS, Thévenin T, El Alaoui-Faris FE. 2017. Inventaire et état de conservation des plantes aromatiques et médicinales (PAM) au Maroc. Phytothérapie 15(3):114-122. doi:10.1007/s10298-017-11312.

Jeddi M, Ouaritini ZB and Fikri-Benbrahim K. 2021. Ethnobotanical study of medicinal plants in northern Morocco (Taounate): case of Mernissa. Ethnobotany Research \& Applications 21: 1-23. doi.org/10.32859/era.21.35.1-23.

Jdaidi N, Hasnaoui B. 2016. Etude floristique et ethnobotanique des plantes médicinales au nord-ouest de la Tunisie: cas de la communauté d'Ouled Sedra. Journal of Advanced Research in Science and Technology 3(1):281291.

Khabbach A, Libiad M, Ennabili A, Bousta D. 2012. Medicinal and cosmetic use of plants from the province of Taza, Northern Morocco. Boletín Latinoamericano y del Caribe de Plantas Medicinales y Aromáticas 11(1):46-60.

Khouchlaa A, Tijane M, Chebat A, Hseini S, Kahouadji A. 2017. Enquête ethnopharmacologique des plantes utilisées dans le traitement de la lithiase urinaire au Maroc. Phytothérapie 15(5):274-287. doi:10.1007/s10298-016-1073-4.

Labiad H, Et-tahir A, Ghanmi M, Satrani B, Aljaiyash A, Chaouch A, Fadli M.2020. Ethnopharmacological survey of aromatic and medicinal plants of the pharmacopoeia of northern Morocco. Ethnobotany Research \& Applications 19:1-16. doi.org/10.32859/era.19.45.1-1. 
Lahsissene H, Kahouadji A, Hseini S. 2009. Catalogue des plantes médicinales utilisées dans la région de Zaër (Maroc Occidental). Lejeunia 186.

Lahsissene H, Kahouadji A. 2010. Analyse ethnobotanique des plantes médicinales et aromatiques de la flore marocaine : cas de la région de Zaër. Phytothérapie 8(4):202-209. doi:10.1007/s10298-010-0569-2.

Manandhar S, Luitel S, Dahal RK. 2019. In vitro antimicrobial activity of some medicinal plants against human pathogenic bacteria. Journal of Tropical Medicine 2019:1895340. https://doi.org/10.1155/2019/1895340.

Mechchate H, Es-Safi I, Zahra Jawhari F, Bari A, Grafov A, Bousta D. 2020. Ethnobotanical survey about the management of diabetes with medicinal plants used by diabetic patient in Region of Fez-Meknes, Morocco. Ethnobotany Research and Applications 19:1-28. doi:10.32859/era.19.12.1-28.

Najem M, Belaidi R, Harouak H, Bouiamrine EH, Ibijbijen J, Nassiri L. 2018. Occurrence de plantes toxiques en phytothérapie traditionnelle dans la région du Moyen Atlas central Maroc. Journal of Animal \& Plant Sciences 35(2):5651-5673.

Orch H, Douira A, Zidane L. 2015. Étude ethnobotanique des plantes médicinales utilisées dans le traitement du diabète, et des maladies cardiaques dans la région d'Izarène (Nord du Maroc). Journal of Applied Biosciences 86(1):7940. doi:10.4314/jab.v86i1.3.

Rejdali M. 1996. Laflore du Maroc: Etat actuel et perspectives de conservation, diversité biologique et valorisation des plantes médicinales. Actes 17-22.

Rhattas M, Douira A, Zidane L .2016. Étude ethnobotanique des plantes médicinales dans le Parc National de Talassemtane (Rif occidental du Maroc). Journal of Applied Biosciences 97:9187 - 9211.

Salhi S, Fadli M, Zidane L, Douira A. 2010. Etudes floristique et ethnobotanique des plantes médicinales de la ville de Kénitra (Maroc). Lazaroa 31:133-146. doi:10.5209/rev_LAZA.2010.v31.9.

Samake KDK. 2012. Contribution à l'identification des plantes médicinales consommées par les patients adresses en consultation d'anesthésie au chu gabriel toure. Thèse de Pharmace: Université de Bamakou-Mali.

Silva, M. Nascimento, K. Castro, I. Andrade. (2015), Ethnobotanical survey of medicinal plants used by the community of Sobradinho, Lus Correia, Piau, Brazil. Journal of Medicinal Plants Research 9(32):872-883.

Slimani I, Najem M, Belaidi R, Bachiri L, Bouiamrine E, Nassiri L. 2016. Étude ethnobotanique des plantes médicinales utilisées dans la région de Zerhoun. International Journal of Innovation and Applied Studies 15:846-863.

Skalli S, Hassikou R, Arahou M. 2019. An ethnobotanical survey of medicinal plants used for diabetes treatment in Rabat, Morocco. Heliyon 5(3):e01421. doi:10.1016/j.heliyon.2019.e01421.

Skinner CM, Rangasami J. 2002. Preoperative use of herbal medicines: a patient survey. British J. of Anaesthesia 89(5):792-795. doi:10.1093/bja/89.5.792.

Sreekeesoon DP, Mahomoodally MF. 2014. Ethnopharmacological analysis of medicinal plants and animals used in the treatment and management of pain in Mauritius. Journal of Ethnopharmacology 157:181-200. doi:10.1016/j.jep.2014.

Tahraoui A, El-Hilaly J, Israili ZH, Lyoussi B. 2007. Ethnobotanical survey of plants used in the traditional treatment of hypertension and diabetes in southeastern Morocco (Errachidia province). Journal of Ethnopharmacology 110:105-117.

Tahri N, El-Basti A, Zidane L, Rochdi A, Douira A. 2012. Ethnobotanical study of medicinal plants in the province of Settat (Morocco). Kastamonu Üniversitesi Orman Fakültesi Dergisi 12(2):192-208.

Tardío J, Pardo-de-Santayana M. 2008. Cultural importance indices: a comparative analysis based on the useful wild plants of Southern Cantabria (Northern Spain). Economic Botany 62(1):24-39. doi:10.1007/s12231-007-9004-5.

Youbi AEHE, Ouahidi I, Mansouri LE, Daoudi A, Bousta D. 2016. Ethnopharmacological survey of plants used for immunological diseases in four regions of Morocco. European Journal of Medicinal Plants 13(1):1-24. https://doi.org/10.9734/EJMP/2016/12946.

Ziyyat A, Legssyer A, Mekhfi H, Dassouli A, Serhrouchni M, Benjelloun W. 1997. Phytotherapy of hypertension and diabetes in oriental Morocco. Journal of Ethnopharmacology 58(1):45-54. doi:10.1016/s0378-8741(97)00077. 
Table 3. List of medicinal and aromatic plant species used by the local population in the province of Taouante (Pre-rif of Morocco).

\begin{tabular}{|c|c|c|c|c|c|c|c|c|}
\hline Families and Species & Vernacular name & Part used & Solvent & $\begin{array}{l}\text { Plant } \\
\text { type }\end{array}$ & FC & RFC & FIV & Related references \\
\hline Agavaceae & & & & & & & 4,512 & \\
\hline Agave americana $\mathrm{L}$. & صبرة Sabera صبرة & lv, st & WS & S & 31 & 4,51 & & (Hachi et al. 2015, Alami et al. 2021) \\
\hline Amaranthaceae & & & & & & & 1,018 & \\
\hline Beta vulgaris $\mathrm{L}$. & البربة L-barba & $\mathrm{bl}$ & h,ws & C & 7 & 1,01 & & (Benkhnigue et al. 2010, Alami et al. 2021) \\
\hline Anacardiaceae & & & & & & & 5,385 & \\
\hline Pistacia atlantica Desf & البطم El- btem & lv & w, ws & $\mathrm{S}$ & 12 & 1,74 & & $\begin{array}{l}\text { (Bellakhdar et al. 1991, El-Hilaly et al. 2003, Alami et al. } \\
\text { 2021) }\end{array}$ \\
\hline Pistacia lentiscus $\mathrm{L}$. & Dرو Drou Dرو & lv & w,ws & S & 62 & 9,02 & & $\begin{array}{l}\text { (Bellakhdar et al. 1991, El-Hilaly et al. 2003, Es-Safi et al. } \\
\text { 2020) }\end{array}$ \\
\hline Apiaceae & & & & & & & 2,878 & \\
\hline Apium graveolens $\mathrm{L}$. & كر افص Krafas & $\begin{array}{l}\text { ap, lv,sd, } \\
\text { wp }\end{array}$ & w & $\mathrm{C} / \mathrm{I}$ & 16 & 2,3 & & $\begin{array}{l}\text { (Bellakhdar, 1997, El-Hilaly et al. 2003, Bouayyadi et al. 2015, } \\
\text { El Hachlafi et al. 2020, Es-Safi et al. 2020, Mechchate et al. } \\
\text { 2020) }\end{array}$ \\
\hline Carum carvi L. & | القروية El-karwiya & fr, sd & w & I & 2 & 0,29 & & $\begin{array}{l}\text { (Bellakhdar, 1997, El-Hilaly et al. 2003, El Hachlafi et al. 2020, } \\
\text { Mechchate et al. 2020) }\end{array}$ \\
\hline Coriandrum sativum $\mathrm{L}$. & Quasbor قسبور & ap ,lv, sd & W & $\mathrm{C} / \mathrm{I}$ & 37 & 5,38 & & (Bellakhdar, 1997, El-Hilaly et al. 2003, Es-Safi et al. 2020) \\
\hline Cuminum cyminum $\mathrm{L}$. & الكمون El-kamoun & sd & w & I & 21 & 3,05 & & (Bellakhdar, 1997, Bouayyadi et al. 2015, Alami et al. 2021) \\
\hline Eryngium maritimum $\mathrm{L}$. & | زرنيج Zarnij & rt, st & w, ws & S & 11 & 1,6 & & $\begin{array}{l}\text { (Bellakhdar, 1997, El-Hilaly et al. 2003, Rhattas et al. 2016, } \\
\text { Alami et al. 2021) }\end{array}$ \\
\hline Foeniculum vulgare Mill. & نافع Nafaâ, Besbass & sd & w & I & 15 & 2,18 & & $\begin{array}{l}\text { (Bellakhdar, 1997, Chebat et al. 2014, El Hachlafi et al. 2020, } \\
\text { Es-Safi et al. 2020, Mechchate et al. 2020) }\end{array}$ \\
\hline Petroselinum crispum Mill. & Maâdnous معندوس & $\begin{array}{ll}\text { ap } & \text {,lv,sd, } \\
\text { wp }\end{array}$ & w & $\mathrm{C} / \mathrm{I}$ & 40 & 5,82 & & $\begin{array}{l}\text { (Bellakhdar, 1997, Tahraoui et al. 2007, Bouayyadi et al. } \\
\text { 2015, El Hachlafi et al. 2020, Es-Safi et al. 2020) }\end{array}$ \\
\hline Pimpinella anisum $\mathrm{L}$. & مبة حلاوة Habat hlawa & $\mathrm{fr}, \mathrm{lv}, \mathrm{sd}$ & w & I & 12 & 1,74 & & $\begin{array}{l}\text { (El-Hilaly et al. 2003, Tahraoui et al. 2007, Benkhnigue et al. } \\
\text { 2014, El Hachlafi et al. 2020, Alami et al. 2021) }\end{array}$ \\
\hline Visnaga daucoides Gaertn. & Bouchnikha بوشنيخة & $\begin{array}{l}\text { ap , fr, sd, } \\
\text { st }\end{array}$ & w, ws & S & 24 & 3,49 & & (Bellakhdar, 1997, El-Hilaly et al. 2003, Alami et al. 2021) \\
\hline Apocynaceae & & & & & & & 10,917 & \\
\hline Nerium oleander $\mathrm{L}$. & Dafla دفلة Da & ap, lv, st & w, ws & S & 75 & 10,91 & & $\begin{array}{l}\text { (Bellakhdar, 1997, El-Hilaly et al. 2003, Jaadan et al. 2020, } \\
\text { Alami et al. 2021) }\end{array}$ \\
\hline
\end{tabular}




\begin{tabular}{|c|c|c|c|c|c|c|c|c|}
\hline Arecaceae & & & & & & & 2,692 & \\
\hline Arum maculatum $\mathrm{L}$ & برنة Yerna & $\mathrm{rt}$ & WS & $\mathrm{S}$ & 22 & 3,2 & & (El-Hilaly et al. 2003, Jaadan et al 2020, Alami et al. 2021) \\
\hline Chamaerops humilis $\mathrm{L}$. & $\begin{array}{l}\text { Dom (lâzaf) الدوف) (لعزف) } \\
\text { الدوم }\end{array}$ & fr , lv & $m, w, w s$ & $\mathrm{~S}$ & 15 & 2,18 & & $\begin{array}{l}\text { (El-Hilaly et al. 2003, Bouayyadi et al. 2015, Alami et al. } \\
\text { 2021) }\end{array}$ \\
\hline Aristolochiaceae & & & & & & & 1,164 & \\
\hline Aristolochia longa L. & برزطم Berez'tem & $\begin{array}{l}\text { lv, rt, sd, } \\
\text { rh }\end{array}$ & w, ws & $\mathrm{S}$ & 8 & 1,16 & & $\begin{array}{l}\text { (Bellakhdar, 1997, El-Hilaly et al. 2003, Chebat et al. 2014, El } \\
\text { Hachlafi et al. 2020, Es-Safi et al. 2020) }\end{array}$ \\
\hline Asteraceae & & & & & & & 6,194 & \\
\hline Artemisia absinthium $\mathrm{L}$. & شيبة Chiba & ap, lv, st & w, ws & C & 63 & 9,17 & & $\begin{array}{l}\text { (El-Hilaly et al. 2003, Jaadan et al. 2020, Mechchate et al. } \\
\text { 2020, El Hachlafi et al. 2020, Es-Safi et al. 2020, Alami et al. } \\
\text { 2021) }\end{array}$ \\
\hline Artemisia herba-alba Asso & شيح Chih & $\mathrm{fl}, \mathrm{lv}, \mathrm{rt}$ & $\mathrm{m}, \mathrm{w}, \mathrm{ws}$ & $\mathrm{C} / \mathrm{I}$ & 98 & 14,26 & & $\begin{array}{l}\text { (Bellakhdar, 1997, El-Hilaly et al. 2003, Tahraoui et al. 2007, } \\
\text { El Hachlafi et al. 2020, Es-Safi et al. 2020, Mechchate et al. } \\
\text { 2020) }\end{array}$ \\
\hline Chamaemelum nobile (L.) & \begin{tabular}{|lll} 
All. & Babounj & romi \\
البابونج رومي
\end{tabular} & $\mathrm{fl}, \mathrm{lv}$ & w & $S$ & 41 & 5,96 & & $\begin{array}{l}\text { (Bellakhdar, 1997, Tahraoui et al. 2007, Salhi et al. 2010, Es- } \\
\text { Safi et al. 2020, Mechchate et al. 2020, Alami et al. 2021) }\end{array}$ \\
\hline Conyza canadenis $\mathrm{L}$ & El âtassa العطاسة & lv & w, ws & S & 13 & 1,89 & & (Bellakhdar et al. 1991, El-Hilaly et al. 2003) \\
\hline Cynara scolymus L. & $\begin{array}{l}\text { Kرشف Khorchef } \\
\text { (القوق) }\end{array}$ & $\mathrm{fl}, \mathrm{rt}$ & w & C & 19 & 2,76 & & $\begin{array}{l}\text { (Bellakhdar, 1997, Benkhnigue et al. 2010, Bouayyadi et al. } \\
\text { 2015, Alami et al. 2021) }\end{array}$ \\
\hline $\begin{array}{l}\text { Dittrichia viscosa (L.) } \\
\text { Greuter }\end{array}$ & | مغركلان Tareeklan & lv , rt, sd & w, ws & $\mathrm{S}$ & 67 & 9,75 & & $\begin{array}{l}\text { (Bellakhdar, 1997, Bouayyadi et al. 2015, Es-Safi et al. 2020, } \\
\text { Alami et al. 2021) }\end{array}$ \\
\hline Lactuca sativa $\mathrm{L}$. & خص Khoss & ap, lv & $\mathrm{m}, \mathrm{w}, \mathrm{ws}$ & C & 6 & 0,87 & & $\begin{array}{l}\text { (Benkhnigue et al. 2010, El Alami et al. 2017, Alami et al. } \\
\text { 2021) }\end{array}$ \\
\hline Matricaria chamomilla $\mathrm{L}$ & |البابونج All babounj & $\mathrm{fl}, \mathrm{lv}$ & w & $\mathrm{S}$ & 61 & 8,87 & & $\begin{array}{l}\text { (Labiad et al. 2020, Jaadan et al. } 2020 \text { Alami et al. 2021, EL- } \\
\text { assri et al. 2021) }\end{array}$ \\
\hline $\begin{array}{l}\text { Silybum marianum (L.) } \\
\text { Gaertn. }\end{array}$ & |Chouklahmir. شوك لحمار & lv , sd & ws & $\mathrm{S}$ & 15 & 2,18 & & $\begin{array}{l}\text { (Bellakhdar, 1997, Bouayyadi et al. 2015, Orch et al. 2015, El } \\
\text { Hachlafi et al. 2020) }\end{array}$ \\
\hline \multicolumn{9}{|l|}{ Boraginaceae } \\
\hline Borago officinalis L. & 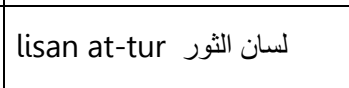 & $\mathrm{fl}, \mathrm{lv}, \mathrm{rh}$ & w & S & 18 & 2,62 & & $\begin{array}{l}\text { (El-Hilaly et al. 2003, El Hassani et al. 2013, Jaadan et al. } \\
\text { 2020, Alami et al. 2021) }\end{array}$ \\
\hline Brassicaceae & & & & & & & 0,873 & \\
\hline Brassica rapa L. & Left & lv & $\mathrm{m}, \mathrm{w}$ & C & 6 & 0,87 & & (Bellakhdar, 1997; Bouayyadi et al. 2015) \\
\hline Lepidium sativum $\mathrm{L}$ & $\begin{array}{l}\text { Habb er- chad } \\
\text { حبة الرشاد (الحرف) }\end{array}$ & sd & w & I & 9 & 1,31 & & $\begin{array}{l}\text { (Bellakhdar, 1997, Tahraoui et al. 2007, Bouayyadi et al. } \\
\text { 2015, Eddouks et al. 2017, Mechchate et al. 2020) }\end{array}$ \\
\hline Sinapis arvensis L. & بوحمو Bouhamo & lv & W & $\mathrm{S}$ & 3 & 0,43 & & (Bellakhdar 1997; Bouayyadi et al. 2015) \\
\hline
\end{tabular}




\begin{tabular}{|c|c|c|c|c|c|c|c|c|}
\hline Cactaceae & & & & & & & 6,841 & \\
\hline $\begin{array}{l}\text { Opuntia ficus-indica (L.) } \\
\text { Mill. }\end{array}$ & Handiya هندية & $\mathrm{fl}, \mathrm{fr}, \mathrm{lv}$ & W,WS & C & 47 & 6,84 & & $\begin{array}{l}\text { (El-Hilaly et al. 2003, Tahraoui et al. 2007, Bouayyadi et al. } \\
\text { 2015, Eddouks et al. 2017, El Hachlafi et al. 2020, Es-Safi et } \\
\text { al. 2020, Mechchate et al. 2020) }\end{array}$ \\
\hline Cannabaceae & & & & & & & 3,347 & \\
\hline Cannabis sativa $\mathrm{L}$. & | الكيف El-kif & $\begin{array}{l}\text { ap , lv, sd } \\
\text {,st }\end{array}$ & Ws & $\mathrm{C} / \mathrm{I}$ & 23 & 3,34 & & (Bellakhdar, 1997, El-Hilaly et al. 2003, Alami et al. 2021) \\
\hline Capparaceae & & & & & & & 14,847 & \\
\hline Capparis spinosa $\mathrm{L}$ & Kabbar كبار & $\mathrm{fl}, \mathrm{fr}$ & $\mathrm{m}, \mathrm{w}$ & $\mathrm{S} / \mathrm{I}$ & 102 & 14,84 & & $\begin{array}{l}\text { (El-Hilaly et al. 2003, Chebat et al. 2014, Bouayyadi et al. } \\
\text { 2015, Jaadan et al. 2020, Alami et al. 2021) }\end{array}$ \\
\hline Caryophyllaceae & & & & & & & 3,566 & \\
\hline Arenaria rubra L. & 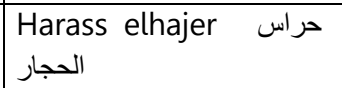 & ap , fl & w & $S / I$ & 40 & 5,82 & & (Benkhnigue et al. 2010) \\
\hline Saponaria officinalis L. & تغيشت Tighicht & lv, rt , sd & w & S & 9 & 1,31 & & (Benkhnigue et al. 2010, Salhi et al. 2010) \\
\hline Chenopodiaceae & & & & & & & 22,27 & \\
\hline $\begin{array}{l}\text { Chenopodium } \\
\text { ambrosioides } \mathrm{L}\end{array}$ & مخينزة Mkhinza & ap, lv & w, ws & $\mathrm{S}$ & 153 & 22,27 & & $\begin{array}{l}\text { (Bellakhdar, 1997, Hilaly et al. 2003, Salhi et al. 2010, El } \\
\text { Hachlafi et al. 2020, Es-Safi et al. 2020, El- Mechchate et al. } \\
\text { 2020) }\end{array}$ \\
\hline Cistaceae & & & & & & & 1,746 & \\
\hline Cistus ladanifer $\mathrm{L}$. & Touzal & $\mathrm{fe}, \mathrm{fl}$ & Ws & S & 12 & 1,74 & & (Najem et al. 2018) \\
\hline Cucurbitaceae & & & & & & & 2,183 & \\
\hline Bryona dioica $\mathrm{L}$. & عنب ديب & $\mathrm{rt}$ & WS & S & 21 & 3,05 & & (El-Hilaly et al. 2003) \\
\hline Cucurbita pepo L. & كرعة الحمر Garâa lhamra & $\mathrm{fr}, \mathrm{sd}$ & WS & C & 9 & 1,31 & & (El-Hilaly et al. 2003, Alami et al. 2021) \\
\hline Cupressaceae & & & & & & & 11,353 & \\
\hline $\begin{array}{l}\text { Tetraclinis articulata (Vahl) } \\
\text { Mast. }\end{array}$ & | El-âarâar العرعار & fr, lv & w, ws & $S$ & 78 & 11,35 & & $\begin{array}{l}\text { (Bellakhdar, 1997, El-Hilaly et al. 2003, El Hassani et al. 2013, } \\
\text { Bouayyadi et al. 2015, Jaadan et al. 2020, Alami et al. 2021) }\end{array}$ \\
\hline Ericaceae & & & & & & & 3,056 & \\
\hline Arbutus unedo L. & باخنو & fr, lv & $\mathrm{m}, \mathrm{w}, \mathrm{ws}$ & Sauvage & 21 & 3,05 & & (El-Hilaly et al. 2003, Es-Safi et al. 2020, Alami et al. 2021) \\
\hline Fabaceae & & & & & & & 5,07 & \\
\hline Ceratonia siliqua $\mathrm{L}$. & El kharob لخروب E E E & fr, lv & w, ws & C & 77 & 11,2 & & $\begin{array}{l}\text { (El-Hilaly et al. 2003, El Hassani et al. 2013, Barkaoui et al. } \\
\text { 2017, Bouyahya et al. 2017, El Hachlafi et al. 2020, Es-Safi et } \\
\text { al. 2020, Mechchate et al. 2020) }\end{array}$ \\
\hline Glycyrrhiza glabra L & ark sous عرق سوس & rt, rh & ws & I & 21 & 3,05 & & $\begin{array}{l}\text { (Ghourri et al. 2013, El Yahyaoui et al. 2015, Bouayyadi et al. } \\
\text { 2015, El Hilah et al. 2016, Es-Safi et al. 2020, Alami et al. } \\
\text { 2021) }\end{array}$ \\
\hline Medicago sativa $\mathrm{L}$. & الفصة Lfasa & ap, lv, st & w, ws & C & 3 & 0,43 & & (El-Hilaly et al. 2003, Alami et al. 2021) \\
\hline
\end{tabular}




\begin{tabular}{|c|c|c|c|c|c|c|c|c|}
\hline Ononis natrix $\mathrm{L}$. & | & ap, lv rt & Ws & S & 32 & 4,65 & & (El-Hilaly et al. 2003, Alami et al. 2021) \\
\hline Retama raetam (Forssk.) & Ratam נم & lv, st & Ws & $\mathrm{S}$ & 2 & 0,29 & & (El-Hilaly et al. 2003, Alami et al. 2021) \\
\hline $\begin{array}{l}\text { Trigonella foenum } \\
\text { graecum } \mathrm{L} \text {. }\end{array}$ & الحلبة L-halba & sd & $m, o, w$ & $C / I$ & 74 & 10,77 & & $\begin{array}{l}\text { (El-Hilaly et al. 2003, Tahraoui et al. 2007, Lahsissene et al. } \\
\text { 2009, Barkaoui et al. 2017, El Hachlafi et al. 2020, Es-Safi et } \\
\text { al. 2020, Mechchate } \text { et al. 2020) }\end{array}$ \\
\hline Fagaceae & & & & & & & 3,639 & \\
\hline Quercus suber $\mathrm{L}$ & | البلوط Al-balot & fr, lv & w, ws & $\mathrm{S} / \mathrm{C}$ & 25 & 3,63 & & $\begin{array}{l}\text { (El-Hilaly et al. 2003, Bouayyadi et al. 2015, Alami et al. } \\
\text { 2021) }\end{array}$ \\
\hline Gentianaceae & & & & & & & 0,873 & \\
\hline Centaurium erythraea Rafn & قصة الحية Kassat lhaya & ap, fl, lv & ws & $S$ & 6 & 0,87 & & $\begin{array}{l}\text { (Bellakhdar, 1997, El-Hilaly et al. 2003, Tahraoui et al. 2007, } \\
\text { El Hassani et al. 2013, Bouayyadi et al. 2015) }\end{array}$ \\
\hline Iridaceae & & & & & & & 1,601 & \\
\hline Crocus sativus $\mathrm{L}$. & | زعفران الحر Zaâfran l'horr| & $\mathrm{fl}$ & w & I & 11 & 1,6 & & (Bellakhdar, 1997, Benlamdini et al. 2014) \\
\hline Juglandaceae & & & & & & & 5,967 & \\
\hline Juglans regia L. & $\begin{array}{l}\text { Sswâk, El gargaâ } \\
\text { الكركاع }\end{array}$ & $\mathrm{fl}, \mathrm{fr}, \mathrm{pe}, \mathrm{rt}$ & w, ws & $C / I$ & 41 & 5,96 & & $\begin{array}{l}\text { (Ziyyat et al. 1997, Bellakhdar, 1997, El-Hilaly et al. 2003, } \\
\text { Benkhnigue et al. 2010, Ghourri et al. 2013, Bouayyadi et al. } \\
\text { 2015, Alami et al. 2021) }\end{array}$ \\
\hline Juncaceae & & & & & & & 4,221 & \\
\hline Juncus acutus $\mathrm{L}$. & Assemar السمار & ap & Ws & S & 29 & 4,22 & & (Bellakhdar, 1997, El-Hilaly et al. 2003, Alami et al. 2021) \\
\hline Lamiaceae & & & & & & & 13,327 & \\
\hline Ajuga iva (L.) & شندكورة Chendgûra & lv, rt & ws & $S$ & 31 & 4,51 & & $\begin{array}{l}\text { (Bellakhdar, 1997, El-Hilaly et al. 2003, Khabbach et al. 2012, } \\
\text { Ghourri et al. 2013, Bouayyadi et al. 2015, Es-Safi et al. 2020) }\end{array}$ \\
\hline $\begin{array}{l}\text { Calamintha officinalis } \\
\text { Moench. }\end{array}$ & مانتة Manta & fe, pa, tg & $\mathrm{m}, \mathrm{w}$ & $S$ & 50 & 7,27 & & $\begin{array}{l}\text { (El-Hilaly et al. 2003, Bouayyadi et al. 2015, Mechchate et al. } \\
\text { 2020) }\end{array}$ \\
\hline Lavandula multifida L. & | حليحلة Hlihla & ap, lv, rt & w, ws & $\mathrm{S}$ & 78 & 11,35 & & (El-Hilaly et al. 2003, Es-Safi et al. 2020) \\
\hline Lavandula officinalis L. & الخزامة Lakhzama & ap, lv & $\mathrm{m}, \mathrm{w}$ & $\mathrm{S}$ & 76 & 11,06 & & (El-Hilaly et al. 2003, Bouayyadi et al. 2015) \\
\hline Lavandula stoechas L. & الحلحال Lhalhal & $\mathrm{fl}, \mathrm{lv}$ & $m, w, w s$ & S & 56 & 8,15 & & (Es-Safi et al. 2020, Mechchate et al. 2020, Alami et al. 2021) \\
\hline Marrubium vulgare $\mathrm{L}$. & Meriwa مريوة & ap , lv, st & $\mathrm{m}, \mathrm{w}$ & $S$ & 59 & 8,58 & & $\begin{array}{l}\text { (El-Hilaly et al. 2003, Salhi et al. 2010, Khabbach et al. 2012, } \\
\text { Tahri et al. 2012, Es-Safi et al. 2020, Mechchate et al. 2020) }\end{array}$ \\
\hline Mentha pulegium $\mathrm{L}$. & فلايو Flayou & ap, lv, st & $\mathrm{m}, \mathrm{w}$ & $S$ & 250 & 36,39 & & $\begin{array}{l}\text { (El-Hilaly et al. 2003, Tahraoui et al. 2007, Khabbach et al. } \\
\text { 2012, Benlamdini et al. 2014, Mechchate et al. 2020) }\end{array}$ \\
\hline Mentha rotundifolia Muds & \begin{tabular}{|l} 
Marseta;Mchachtro \\
مشاشترو \\
\end{tabular} & ap, lv, st & $\mathrm{m}, \mathrm{w}, \mathrm{ws}$ & $S$ & 93 & 13,56 & & $\begin{array}{l}\text { (El-Hilaly et al. 2003, Benkhnigue et al. 2010, Salhi et al. } \\
\text { 2010) }\end{array}$ \\
\hline Mentha viridis $\mathrm{L}$ & Naânaâ نعناع & ap, lv, st & w, ws & C & 32 & 4,65 & & $\begin{array}{l}\text { (Bellakhdar, 1997, El-Hilaly et al. 2003, Benkhnigue et al. } \\
\text { 2010, Bouayyadi et al. 2015, Alami et al. 2021) }\end{array}$ \\
\hline
\end{tabular}


Ethnobotany Research and Applications

\begin{tabular}{|c|c|c|c|c|c|c|c|c|}
\hline Ocimum basilicum $\mathrm{L}$. & الحباق Lhbak & ap , lv, sd & w & C & 32 & 4,65 & & $\begin{array}{l}\text { (Ziyyat et al. 1997, El-Hilaly et al. 2003, Tahraoui et al. 2007, } \\
\text { Salhi et al. 2010, Bouyahya et al. 2017, El Hachlafi et al. 2020, } \\
\text { Alami et al. 2021) }\end{array}$ \\
\hline $\begin{array}{l}\text { Origanum compactum } \\
\text { Benth. }\end{array}$ & زعتر Zaâter & lv , sd & $m, w, w s$ & $S$ & 301 & 43,81 & & $\begin{array}{l}\text { (El-Hilaly et al. 2003, Benlamdini et al. 2014, Bouyahya et al. } \\
\text { 2017, El Hachlafi et al. 2020, Es-Safi et al. 2020, Mechchate } \text { et } \\
\text { al. 2020) }\end{array}$ \\
\hline Origanum majorana L. & مرددوش Mardadouch & lv & $\mathrm{m}, \mathrm{w}, \mathrm{ws}$ & $S$ & 21 & 3,05 & & $\begin{array}{l}\text { (Ziyyat et al. 1997, El-Hilaly et al. 2003, Tahraoui et al. 2007, } \\
\text { Salhi et al. 2010, Khabbach et al. 2012, Fadil et al. 2015, El } \\
\text { Hachlafi et al. 2020, Es-Safi et al. 2020, Alami et al. 2021) }\end{array}$ \\
\hline Rosmarinus officinalis $\mathrm{L}$. & Azir أزير & ap, lv, rt & $\mathrm{m}, \mathrm{w}, \mathrm{ws}$ & $C / S$ & 212 & 30,85 & & $\begin{array}{l}\text { (El-Hilaly et al. 2003, Salhi et al. 2010, Eddouks et al. 2017, El } \\
\text { Hachlafi et al. 2020, Es-Safi et al. 2020, Mechchate et al. } \\
\text { 2020) }\end{array}$ \\
\hline Salvia officinalis L. & Salmiya سالمية Sa & lv & $\mathrm{m}, \mathrm{w}$ & $C / S$ & 70 & 10,18 & & $\begin{array}{l}\text { (Ghourri et al. 2013, Orch et al. 2015, Bouayyadi et al. 2015, } \\
\text { Bouyahya et al. 2017, Eddouks et al. 2017, El Hachlafi et al. } \\
\text { 2020, Mechchate et al. 2020) }\end{array}$ \\
\hline Salvia verbenaca $\mathrm{L}$. & خiyyâta خياطة & lv & w, ws & $\mathrm{S} / \mathrm{I}$ & 22 & 3,2 & & $\begin{array}{l}\text { (Benlamdini et al. 2014, Bouayyadi et al. 2015, Alami et al. } \\
\text { 2021) }\end{array}$ \\
\hline Thymus vulgaris $\mathrm{L}$ & زعيترة زaitra & ap, fl, , lv & $m, w$ & $S$ & 82 & 11 & & $\begin{array}{l}\text { (Ghourri et al. 2013, Fadil et al. 2015, El Hachlafi et al. 2020, } \\
\text { Mechchate et al. 2020, Alami et al. 2021) }\end{array}$ \\
\hline Lauraceae & & & & & & & 2,037 & \\
\hline $\begin{array}{l}\text { Cinnamomum verum } \\
\text { Berchtold \& J. S. Presl }\end{array}$ & Qرفة Qarfa, Karfa & pe, st & W,ws & I & 21 & 3,05 & & $\begin{array}{l}\text { (Benkhnigue et al. 2010, El Yahyaoui et al. 2015, Orch et al. } \\
\text { 2015, Yahyaoui et al. 2015, Mechchate et al. 2020) }\end{array}$ \\
\hline Laurus nobilis L & $\begin{array}{|ll|}\text { Awrak sidna moussa } \\
\text { اوراق سيدنا موسى }\end{array}$ & lv & W,ws & 1 & 12 & 1,74 & & (Bellakhdar, 1997, Hachi et al. 2015, Alami et al. 2021) \\
\hline Persea americana Mill. & Avocat & $\mathrm{fr}$ & W,ws & 1 & 9 & 1,31 & & $\begin{array}{l}\text { (Bellakhdar, 1997, Benkhnigue et al. 2010, Bouayyadi et al. } \\
\text { 2015, El Hachlafi et al. 2020) }\end{array}$ \\
\hline Liliaceae & & & & & & & 9,17 & \\
\hline Allium cepa L. & | El-bassla البصلة E & bl & ws & $C / I$ & 53 & 7,71 & & $\begin{array}{l}\text { (El-Hilaly et al. 2003, Chebat et al. 2014, Youbi et al. 2016, } \\
\text { Barkaoui et al. 2017, El Hachlafi et al. 2020, Es-Safi et al. } \\
\text { 2020, Mechchate } \text { et al. 2020, Alami et al. 2021) }\end{array}$ \\
\hline Allium sativum $\mathrm{L}$. & | التومة El touma & bl & $\mathrm{O}, \mathrm{w}$ & $\mathrm{C} / \mathrm{I}$ & 121 & 17,61 & & $\begin{array}{l}\text { (Eddouks et al. 2002, El-Hilaly et al. 2003, Bouayyadi et al. } \\
\text { 2015, Orch et al. 2015, Barkaoui et al. 2017, El Hachlafi et al. } \\
\text { 2020, Es-Safi et al. 2020, Mechchate et al. 2020, Alami et al. } \\
\text { 2021) }\end{array}$ \\
\hline $\begin{array}{l}\text { Charybdis maritima (L.) } \\
\text { Speta }\end{array}$ & | El basiila البصيلة & bl & ws & $S$ & 15 & 2,18 & & (El-Hilaly et al. 2003, Salhi et al. 2010) \\
\hline
\end{tabular}




\begin{tabular}{|c|c|c|c|c|c|c|c|c|}
\hline Linaceae & & & & & & & 1,601 & \\
\hline Linum usitatissimum L. & 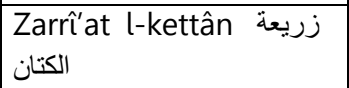 & sd & w, ws & $C / I$ & 11 & 1,6 & & $\begin{array}{l}\text { (Yahyaoui et al. 2015, El Hachlafi et al. 2020, Es-Safi et al. } \\
\text { 2020, Mechchate et al. 2020, Alami et al. 2021) }\end{array}$ \\
\hline Lythraceae & & & & & & & 4,949 & \\
\hline Lawsonia inermis $\mathrm{L}$. & El-henna الحنة El & lv & w & I & 34 & 4,94 & & (Bellakhdar, 1997, Alami et al. 2021) \\
\hline Malvaceae & & & & & & & 2,037 & \\
\hline Malva sylvestris $\mathrm{L}$. & خبيزة Khobbeyza & lv, rt & w, ws & $S$ & 14 & 2,03 & & $\begin{array}{l}\text { (Benkhnigue et al. 2010, Bouayyadi et al. 2015, Alami et al. } \\
\text { 2021) }\end{array}$ \\
\hline Moraceae & & & & & & & 8,588 & \\
\hline Ficus carica L. & $\begin{array}{|ll|}\text { El karmôss, Chriha } \\
\text { الكرموس }\end{array}$ & $\mathrm{fr}, \mathrm{lv}$ & $h$, ws & C & 59 & 8,58 & & $\begin{array}{l}\text { (Bellakhdar, 1997, El-Hilaly et al. 2003, Bouyahya et al. 2017, } \\
\text { El Hachlafi et al. 2020, Mechchate et al. 2020) }\end{array}$ \\
\hline Myrtaceae & & & & & & & 5,919 & \\
\hline Eucalyptus ssp & | الكاليتوس El-kalibtouse & lv & w, ws & C & 65 & 9,46 & & $\begin{array}{l}\text { (Bellakhdar, 1997, El-Hilaly et al. 2003, El Hilah et al. 2016, } \\
\text { Bouyhaya et al. } 2017 \text {;) }\end{array}$ \\
\hline Myrtus communis $\mathrm{L}$. & ريحان Rihan & lv & w & $\mathrm{S}$ & 31 & 4,51 & & $\begin{array}{l}\text { (Bellakhdar, 1997, El-Hilaly et al. 2003, Bouyahya et al. 2017, } \\
\text { El Hachlafi et al. 2020, Es-Safi et al. 2020, Mechchate et al. } \\
\text { 2020) }\end{array}$ \\
\hline $\begin{array}{l}\text { Syzygium aromaticum (L.) } \\
\text { Merr. \& Perry }\end{array}$ & Qرنفل ق ق & $\mathrm{fr}, \mathrm{lv}, \mathrm{sd}$ & w & 1 & 26 & 3,78 & & $\begin{array}{l}\text { (Salhi et al. 2010, Benlamdini et al. 2014, Bouayyadi et al. } \\
\text { 2015, El Hilah et al. 2016, Alami et al. 2021) }\end{array}$ \\
\hline Oleaceae & & & & & & & 10,262 & \\
\hline $\begin{array}{l}\text { Olea europaea L. var. } \\
\text { oleaster }\end{array}$ & | El-barri البري & $\mathrm{fr}, \mathrm{lv}$ & w, ws & $S$ & 59 & 8,58 & & (Bellakhdar, 1997, El-Hilaly et al. 2003) \\
\hline $\begin{array}{l}\text { Olea europaea L. var. } \\
\text { sativa }\end{array}$ & | الزيتون El-ziton & $\mathrm{fr}, \mathrm{lv}$ & w, ws & C & 82 & 11,93 & & $\begin{array}{l}\text { (El-Hilaly et al. 2003, Orch et al. 2015, Fadil et al. 2015, } \\
\text { Bouyahya et al. 2017, El Hachlafi et al. 2020, Es-Safi et al. } \\
\text { 2020, Mechchate et al. 2020, Alami et al. } 2021 \text {;) }\end{array}$ \\
\hline Papaveraceae & & & & & & & 1,601 & \\
\hline Papaver rhoeas $\mathrm{L}$. & Balaâman بلعمان & $\mathrm{fl}$, st & w & $\mathrm{S}$ & 11 & 1,6 & & $\begin{array}{l}\text { (El-Hilaly et al. 2003, El Hassani et al. 2013, Es-Safi et al. } \\
\text { 2020, Mechchate et al. 2020, Alami et al. 2021) }\end{array}$ \\
\hline Poaceae & & & & & & & 1,649 & \\
\hline Cynodon dactylon (L.) Pers. & نجم Najm & ap ,lv, rt & ws & $\mathrm{S}$ & 9 & 1,31 & & $\begin{array}{l}\text { (Bellakhdar, 1997, El-Hilaly et al. 2003, Benlamdini et al. } \\
\text { 2014, Alami et al. 2021) }\end{array}$ \\
\hline Hordeum vulgare $\mathrm{L}$. & Chaâir شعير & fr, sd & w, ws & Cultivée & 3 & 0,43 & & $\begin{array}{l}\text { (Benkhnigue et al. 2010, El Alami et al. 2017, Alami et al. } \\
\text { 2021) }\end{array}$ \\
\hline Setaria pallide-fusca & ايلان Ilan & sd & w & I & 22 & 3,2 & & (Bellakhdar, 1997, El-Hilaly et al. 2003) \\
\hline Polygonaceae & & & & & & & 1,892 & \\
\hline Emex spinosa (L.) Campd. & حميضة Hommayda & lv, st & w, ws & $\mathrm{S}$ & 13 & 1,89 & & (El-Hilaly et al. 2003, Hassani et al. 2013) \\
\hline
\end{tabular}




\begin{tabular}{|c|c|c|c|c|c|c|c|c|}
\hline Punicaceae & & & & & & & 8,151 & \\
\hline Punica granatum $\mathrm{L}$. & Raman رمان & $\begin{array}{l}\text { pe } \\
\text { (pericarp) }\end{array}$ & w, ws & C & 56 & 8,15 & & $\begin{array}{l}\text { (El-Hilaly et al. 2003, Bouyahya et al. 2017, El Hachlafi et al. } \\
\text { 2020, Es-Safi et al. 2020, Mechchate et al. 2020, Alami et al. } \\
\text { 2021) }\end{array}$ \\
\hline Ranunculaceae & & & & & & & 3,86 & \\
\hline Clematis flammula $\mathrm{L}$. & النار الباردة Nar lbarda & fr, lv & w & $\mathrm{S}$ & 21 & 3,05 & & $\begin{array}{l}\text { (Benkhnigue et al. 2010, Benlamdini et al. 2014, Bouayyadi } \\
\text { et al. 2015, Alami et al. 2021) }\end{array}$ \\
\hline Nigella sativa L. & 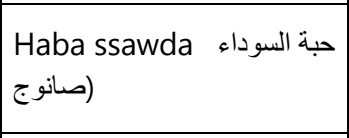 & sd & $h, o$ & I & 33 & 4,8 & & $\begin{array}{l}\text { (El-Hilaly et al. 2003, Benkhnigue et al. 2010, Benlamdini et } \\
\text { al. 2014, El Yahyaoui et al. 2015, El Hachlafi et al. 2020, Es- } \\
\text { Safi et al. 2020, Mechchate et al. 2020) }\end{array}$ \\
\hline Rhamnaceae & & & & & & & 4,404 & \\
\hline Ziziphus lotus (L.) Lam. & | Sadra S السدرة & lv, rt & w, ws & S & 44 & 6,4 & & $\begin{array}{l}\text { (El-Hilaly et al. 2003, Benlamdini et al. 2014, Khouchlaa et al. } \\
\text { 2017, El Hachlafi et al. 2020, Alami et al. 2021) }\end{array}$ \\
\hline Rosaceae & & & & & & & 2,998 & \\
\hline Crataegus monogyna Jacq & Admam أدمام Adm & fr, lv & w, ws & S & 13 & 1,89 & & $\begin{array}{l}\text { (El-Hilaly et al. 2003, Benlamdini et al. 2014, Alami et al. } \\
\text { 2021) }\end{array}$ \\
\hline $\begin{array}{l}\text { Eriobotrya japonica } \\
\text { (Thunb.) Lindl. }\end{array}$ & Lamzah المزاح & fr, lv & WS & C & 9 & 1,31 & & $\begin{array}{l}\text { (Ziyyat et al. 1997, El-Hilaly et al. 2003, Ghourri et al. 2013, } \\
\text { Orch et al. 2015, Alami et al. 2021) }\end{array}$ \\
\hline Rosa centifolia L. & الورد الو Lward & $\mathrm{fl}$ & w, ws & C & 29 & 4,22 & & (Bellakhdar, 1997, El-Hilaly et al. 2003, Alami et al. 2021) \\
\hline Rubus fruticosus L. & أخليج El-aâlig & fr, lv & & $\mathrm{S}$ & 19 & 2,76 & & (Benkhnigue et al. 2010) \\
\hline $\begin{array}{l}\text { Prunus amygdalus Stokes } \\
\text { var. amara L. }\end{array}$ & Louze lmor Lوز المر Lor & fr, sd & w, ws & C & 33 & 4,8 & & (Bellakhdar, 1997, Bouayyadi et al. 2015, Alami et al. 2021) \\
\hline Rutaceae & & & & & & & 2,256 & \\
\hline Citrus limon (L.) Burm. F & ليمون Limoun ليمن & $\mathrm{fl}, \mathrm{fr}$ & $\mathrm{h}, \mathrm{w}$ & $\mathrm{C} / \mathrm{I}$ & 22 & 3,2 & & (Bellakhdar, 1997, El-Hilaly et al. 2003) \\
\hline Citrus aurantium $\mathrm{L}$ & 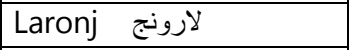 & fr, lv & $\mathrm{h}, \mathrm{w}$ & $\mathrm{C} / \mathrm{I}$. & 9 & 1,31 & & (El-Hilaly et al. 2003, Alami et al. 2021) \\
\hline Salicaceae & & & & & & & 2,765 & \\
\hline Populus alba L. & Safsaf الصفصاف & lv & w, ws & S & 19 & 2,76 & & (Bellakhdar, 1997, El-Hilaly et al. 2003, El Hassani et al. 2013) \\
\hline Sapotaceae & & & & & & & 1,601 & \\
\hline Argania spinosa (L.) Skeels & 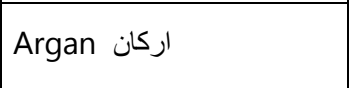 & fr, sd & w & I & 11 & 1,6 & & $\begin{array}{l}\text { (El Hafian et al. 2014, Bouayyadi et al. 2015, El Yahyaoui et } \\
\text { al. 2015, El Hachlafi et al. 2020) }\end{array}$ \\
\hline Solanaceae & & & & & & & 1,31 & \\
\hline Datura stramonium L. & كرنك Kernk & sd, lv & W & $\mathrm{S}$ & 9 & 1,31 & & (El-Hilaly et al. 2003, Alami et al. 2021) \\
\hline Theaceae & & & & & & & 1,31 & \\
\hline $\begin{array}{l}\text { Camellia sinensis (L.) } \\
\text { Kuntze }\end{array}$ & Atây أتاي & lv & w & I & 9 & 1,31 & & $\begin{array}{l}\text { (El Amrani et al. 2010, Doukkali et al. 2015, EL Yahyaoui et al. } \\
\text { 2015, Bouayyadi et al. 2015, El Hachlafi et al. 2020) }\end{array}$ \\
\hline
\end{tabular}




\begin{tabular}{|c|c|c|c|c|c|c|c|c|}
\hline Thymelaeaceae & & & & & & & 2,328 & \\
\hline Aquilaria malaccensis & أغريس Aghriss & lv, pe & $\mathrm{w}$ & 1 & 29 & 4,22 & & (Eddouks et al. 2017) \\
\hline Daphne gnidium L. & لز از & $\mathrm{fr}, \mathrm{lv}$ & $\mathrm{w}$ & $S$ & 3 & 0,43 & & (El-Hilaly et al. 2003, Alami et al. 2021) \\
\hline Urticaceae & & & & & & & 4,949 & \\
\hline Urtica dioica $\mathrm{L}$ & حريقة Horriqa (zotifa) & lv & ws & $S$ & 34 & 4,94 & & $\begin{array}{l}\text { (El-Hilaly et al. 2003, Benkhnigue et al. 2010, Tahri et al. } \\
\text { 2012, Ghourri et al. 2013, Bouayyadi et al. 2015) }\end{array}$ \\
\hline Verbenaceae & & & & & & & 9,825 & \\
\hline Aloysia citriodora Palau & لويزة Lwiza & lv & $\mathrm{m}, \mathrm{w}$ & $\mathrm{C} / \mathrm{I}$ & 123 & 17,9 & & (Alami et al. 2021, Bellakhdar, 1997, Bouayyadi et al. 2015) \\
\hline Vitex agnus-castus $\mathrm{L}$. & الخرواع Kharwaâ & lv & W,Ws & 1 & 12 & 1,74 & & (El-Hilaly et al. 2003, Bouayyadi et al. 2015) \\
\hline Vitaceae & & & & & & & 1,164 & \\
\hline Vitis vinifera $\mathrm{L}$. & 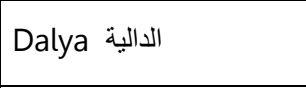 & fr, lv & ws & C & 8 & 1,16 & & $\begin{array}{l}\text { (Benlamdini et al. 2014, Bouayyadi et al. 2015, Alami et al. } \\
\text { 2021) }\end{array}$ \\
\hline Zingiberaceae & & & & & & & 7,423 & \\
\hline Zingiber officinale & زنجبيل zanjabil z z & rt & W & 1 & 51 & 7,42 & & $\begin{array}{l}\text { (Benkhnigue et al. 2010, Ghourri et al. 2013, Bouayyadi et al. } \\
\text { 2015, El Yahyaoui et al. 2015, Alami et al. 2021) }\end{array}$ \\
\hline Zygophyllaceae & & & & & & & 1,164 & \\
\hline Peganum harmala $\mathrm{L}$ & 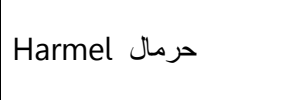 & sd & W & 1 & 8 & 1,16 & & $\begin{array}{l}\text { (Hseini \& Kahouadji, 2007, Salhi et al. 2010, Benkhnigue et } \\
\text { al. 2010, Doukkali et al. 2015) }\end{array}$ \\
\hline
\end{tabular}

Part used: Ap: Aerial part; Bl: Bulbs; Fl: Flowers; Fr: Fruits; Lv: Leaves; Pe: peel; Rh: Rhizome; Rt: Roots; Sd: Seeds; St: Stem; Wp: Whole Plant. Type of plants: C: Cultivated; I: Imported; S: Spontaneous.

Solvent: H: honey; M: milk; O: oil; w: water; WS: without solvent. 